Elsevier Editorial system(tm) for Lithos Manuscript Draft

Manuscript Number: LITHOS6949R1

Title: Phengite megacryst quasi-exsolving phlogopite, from Sulu Ultrahigh Pressure Metamorphic Terrane, Qinglongshan, Donghai County (eastern China): new data for $\mathrm{P}-\mathrm{T}-\mathrm{X}$ conditions during exhumation.

Article Type: Regular Article

Keywords: phengite and phlogopite micas; exolution reactions; Sulu UHP metamorphic terrane; alkali-alumino-silicate high pressure fluids.

Corresponding Author: Dr. Costanza Bonadiman, PhD

Corresponding Author's Institution: University of Ferrara

First Author: Nadia Curetti

Order of Authors: Nadia Curetti; Costanza Bonadiman, PhD; Roberto Compagnoni; Luca Nodari; Indrid Corazzari; Alessandro Pavese

Abstract: A large crystal of trigonal phengite (Phe-3T; $\mathrm{K} 0.96 \mathrm{Na} 0.02 \mathrm{Ba} 0.01)(\mathrm{Al} 1.35 \mathrm{Mg} 0.40 \mathrm{Fe} 2+0.11 \mathrm{Fe}+0.13 \mathrm{Ti} 0.02) \Sigma=2.02[\mathrm{Si} 3.44 \mathrm{Al} 0.56$ ] $010(\mathrm{OH}) 2)$, sampled from a phengite+quartz metamorphic vein in the eclogites-bearing rocks of Sulu UHP metamorphic terrane, exhibits unusual thin lamellae of ferrian-aluminian trigonal/monoclinic phlogopite polytypes (Phl-3T:

$(\mathrm{K} 0.78 \mathrm{Na} 0.01)(\mathrm{Mg} 1.48 \mathrm{Fe} 2+0.39 \mathrm{Fe} 3+0.45 \mathrm{Al} 0.30 \mathrm{Ti} 0.06) \Sigma=2.68[\mathrm{Si2} .98 \mathrm{Al} 1.02] 010($ $(\mathrm{OH}) 1.77 \mathrm{FO} .23) ; \mathrm{Phl}-1 \mathrm{M}$ :

$(\mathrm{K} 0.85 \mathrm{Ca} 0.01)(\mathrm{Mg} 1.43 \mathrm{Fe} 2+0.45 \mathrm{Fe} 3+0.54 \mathrm{Al0} .21 \mathrm{TiO} .06) \Sigma=2.69[\mathrm{Si2} .88 \mathrm{Al} .12] 010($ $(\mathrm{OH}) 1.99 \mathrm{FO} .01)$ ). This assemblage is rarely observed in UHP eclogitebearing rocks, and has never been reported before in the Sulu UHP metamorphic terrane. A detailed crystal-chemical characterisation of Phe3T, Phl-3T and Phl-1M allowed the development of a thermodynamic model that estimates the P-T conditions of formation of such an assemblage and helps to understand the relationship between mica polytypes and a quartz dominated (silica oversaturated) system, which characterized the sulu vein. Phe-3T varies in composition upon approaching Phl-3T/1M, showing a decrease of $\mathrm{Si}$ and $\mathrm{Al}$ and $\mathrm{an}$ increase of $\mathrm{Fe}$ and $\mathrm{Mg}$ contents. Observed phlogopites cannot be ascribed to bare exsolving processes, and require the involvement of a non-isochemical reaction, dominated by exsolution (quasi-exsolution process) in combination with a contribution from an "external chemical supplier" (most probably provided by circulating fluids). Mass balance calculations between the mineralogical assemblage of Sulu vein and the solute components of alkali-alumino-silicate high pressure fluids demonstrate that a silicic-type major element composition accounts for a phengite-quartz based rock. The occurrence of phlogopite micas can be explained as an effect of disproportion in combination with supply components, i.e. Mg, Al and K, from alkali-alumino-silicate high pressure fluids.

On the basis of energy modelling of the reaction process from phengite to phlogopite in presence of quartz and a matter exchanger, we determined that such a transformation is weakly dependent on $\mathrm{T}$ over the $500-930^{\circ} \mathrm{C}$ thermal range. The intersection of the calculated P-T assemblage equilibrium curve with the country rock P-T metamorphic path occurs at 
$\mathrm{P} \sim 2.4 \pm 0.2 \mathrm{GPa}$ and $\mathrm{T} \sim 700^{\circ} \mathrm{C}$, thus reflecting an early stage of exhumation, close to the metamorphic peak of the Sulu UHP terrane. 


\section{Dear Editor,}

The revised version of the manuscript "Phengite megacryst quasi-exsolving phlogopite, from Sulu Ultra-high Pressure Metamorphic Terrane, Qinglongshan, Donghai County (eastern China): new data for P-T-X conditions during exhumation.' has been uploaded.

First of all, the authors are honored to have got a positive feedback about this study from either reviewers, and editor.

We are also thankful for the rigorous editorial work they have paid to our manuscript. In this light, the authors have introduced all the corrections and enhancements suggested by the reviewers. Changes are in red, in the revised manuscript.

For the Authors

Costanza Bonadiman

\section{COMMENTS FROM EDITORS AND REVIEWERS}

Dear Dr. Bonadiman,

two reviews of your manuscript are now available. I am quite glad to see that the reviewer's comments are quite positive as they recommend publication after minor revision and/or acceptance of the paper in the present for.

Compliments for the interesting work.

I look forward to receive the revised manuscript to proceed with acceptance.

With kind regards

Marco Scambelluri

Lithos editor

Reviewer \#1: The manuscript by Curetti et al. describes an un common assemblage of dioctahedral and trioctahedral micas with different polytypes, together with all the thermodynamic reactions leading to the formation of the mentioned assemblage.

The interesting results provided by authors and the sound scientific approach leading to their generation and interpretation deserve publication on Lithos. I certainly recommend publication after fixing some points, mainly related to form rather than to the scientific matter. Some points to be considered for correction are listed below.

Table S1 reports Suluphe instead of Phe-3T as reported throughout the text.

Authors' reply: Thanks for noting. We change accordingly.

Several references reported in the manuscript are not reported in the reference list, e.g. Castelli et al. 1998; Gresen et al. 1971; Goodman 1976; Aldrige et al., 1987; Finch et al. 1982; Shabani et al.1998; Franz et al. 1987. Vice versa many quotations in reference list are not present in the text, e.g. Hermann, J., Rubatto, D., 2014; Ivaldi, G., Curetti, N., Gula, A., 2002; Frank, W., Höck, V., Miller, C.; Hermann, J., Rubatto, D., Korsakov, A., Shatsky, V.S., 2001; Pavese, A., 2002; Pavese, A., Diella, V., 2010; Shaw, D.M., 1970; Wallis, S., Tsuboi, M., Suzuki, K., Fanning, M., Jiang, L.L., Tanaka, T., 2005; Wallis, S., Ishiwatari, A., Hirajima, T., Ye, K., Guo, J., Nakamura, D., Kato, T., Zhai, M., Enami, M., Cong, B., and Banno, S., 1997; Zhang, R-Y., Liou, J.G., Shau, J.F., 2002; Zhang Z-M., Xiao Y-L., Liu F-L., Liou, J.G., and Hoefs, J., 2005; Zhao, Z-F., Zheng, Y- 
F., Zhang, J., Dai, L.Q., Liu, X.M., 2012; Zheng, Y-F., 2012; Zheng, Y-F., Hermann, J., 2014; Zheng, Y-F, Xia, Q-X, Chen, R-X, Gao, X-Y., 2011.

Authors' reply: We apologize for this. It is attributable to the corresponding author who uploaded a preliminary reference-crosschecked version of the manuscript.

The revised version is complete and duly checked for references in each section. The missing references (both in the text and in the reference list) are in red.

Reviewer \#2: The manuscript deals with a rare occurrence of phlogopite in phengite megacryst found in a phengite-quartz vein within the UHP Sulu metamorphic terrane. Profiting of a detailed crystal-chemical analysis including Mossbauer Spectroscopy for the determinationof $\mathrm{Fe} 2+$ and Fe3+ the authors propose a fluiddominated reaction in an open metamorphic system that allow the formation of quasi-exsolving phlogopite. Thermodynamic modeling is then used to determine PT metamorphic conditions of an exhumation stage to be compared with reported metamorphic peak for the Sulu UHP terrane.

The manuscript is well written, the goal clearly explained and all the data well presented.

The topic is certainly of broad scientific interest and deserves to be published in Lithos almost in the present form.

In the following only few minor corrections.

Minor corrections:

lines 51-53: delete "usually hydrous"

Done

line 61: substitute "in dry conditions" with "at dry conditions"

Done

lines 62: move the reference (Poli and Fumagalli 2003) in the end of the sentence. As it is, it seems that Poli and Fumagalli stated that eclogites form at dry conditions.

Authors' reply: thanks for noting. We move the reference accordingly

Best regards.

Patrizia Fumagalli 


\title{
Phengite megacryst quasi-exsolving phlogopite, from Sulu Ultra-high Pressure Metamorphic Terrane, Qinglongshan, Donghai County (eastern China): new data for $P-T-X$ conditions during exhumation
}

Nadia Curetti ${ }^{\mathrm{a}}$, Costanza Bonadiman ${ }^{\mathrm{b}}$, Roberto Compagnoni ${ }^{\mathrm{a},}$ Alessandro Pavese ${ }^{\mathrm{a}}$, Luca Nodari ${ }^{\mathrm{c}}$, Ingrid Corazzari $^{\mathrm{d}, \mathrm{e}}$

\footnotetext{
${ }^{a}$ Department of Earth Sciences, University of Turin, 10125 Turin, Italy

${ }^{\mathrm{b}}$ Department of Physics and Earth Sciences, University of Ferrara, 44122 Ferrara, Italy

${ }^{\mathrm{c}}$ Institute of Condensed Matter Chemistry and Technology for the Energy- CNR - Padua, Italy

${ }^{\mathrm{d}}$ Department of Chemistry, University of Turin, 10125 Turin, Italy

e "G. Scansetti" Interdepartmental Center for Studies on Asbestos and Other Toxic Particulates, Turin, Italy.
}

\begin{abstract}
A large crystal of trigonal phengite

(Phe-3T; $\left.\left.\mathrm{K}_{0.96} \mathrm{Na}_{0.02} \mathrm{Ba}_{0.01}\right)\left(\mathrm{Al}_{1.35} \mathrm{Mg}_{0.40} \mathrm{Fe}^{2+}{ }_{0.11} \mathrm{Fe}^{3+}{ }_{0.13} \mathrm{Ti}_{0.02}\right)_{\Sigma=2.02}\left[\mathrm{Si}_{3.44} \mathrm{Al}_{0.56}\right] \mathrm{O}_{10}(\mathrm{OH})_{2}\right)$, sampled from a phengite+quartz metamorphic vein in the eclogites-bearing rocks of Sulu UHP metamorphic terrane, exhibits unusual thin lamellae of ferrian-aluminian trigonal/monoclinic phlogopite polytypes

$\left(P h l-3 T:\left(\mathrm{K}_{0.78} \mathrm{Na}_{0.01}\right)\left(\mathrm{Mg}_{1.48} \mathrm{Fe}^{2+}{ }_{0.39} \mathrm{Fe}^{3+}{ }_{0.45} \mathrm{Al}_{0.30} \mathrm{Ti}_{0.06}\right)_{\Sigma=2.68}\left[\mathrm{Si}_{2.98} \mathrm{Al}_{1.02}\right] \mathrm{O}_{10}\left((\mathrm{OH})_{1.77} \mathrm{~F}_{0.23}\right) ; P h l-1 M:\right.$

$\left.\left(\mathrm{K}_{0.85} \mathrm{Ca}_{0.01}\right)\left(\mathrm{Mg}_{1.43} \mathrm{Fe}^{2+}{ }_{0.45} \mathrm{Fe}^{3+}{ }_{0.54} \mathrm{Al}_{0.21} \mathrm{Ti}_{0.06}\right)_{\Sigma=2.69}\left[\mathrm{Si}_{2.88} \mathrm{Al}_{1.12}\right] \mathrm{O}_{10}\left((\mathrm{OH})_{1.99} \mathrm{~F}_{0.01}\right)\right)$.
\end{abstract}

This assemblage is rarely observed in UHP eclogite-bearing rocks, and has never been reported before in the Sulu UHP metamorphic terrane. A detailed crystal-chemical characterisation of Phe3T, Phl-3T and Phl-1M allowed the development of a thermodynamic model that estimates the $P-T$ conditions of formation of such an assemblage and helps to understand the relationship between mica polytypes and a quartz dominated (silica oversaturated) system, which characterized the Sulu vein. Phe-3T varies in composition upon approaching Phl-3T/1M, showing a decrease of Si and Al 
and an increase of $\mathrm{Fe}$ and $\mathrm{Mg}$ contents. Observed phlogopites cannot be ascribed to bare exsolving processes, and require the involvement of a non-isochemical reaction, dominated by exsolution (quasi-exsolution process) in combination with a contribution from an "external chemical supplier" (most probably provided by circulating fluids). Mass balance calculations between the mineralogical assemblage of Sulu vein and the solute components of alkali-alumino-silicate high pressure fluids demonstrate that a silicic-type major element composition accounts for a phengitequartz based rock. The occurrence of phlogopite micas can be explained as an effect of disproportion in combination with supply components, i.e. $\mathrm{Mg}, \mathrm{Al}$ and $\mathrm{K}$, from alkali-aluminosilicate high pressure fluids. 
1 Phengite megacryst quasi-exsolving phlogopite, from Sulu Ultra-high Pressure

2 Metamorphic Terrane, Qinglongshan, Donghai County (eastern China): new data for $3 \quad P-T-X$ conditions during exhumation.

4 by Nadia Curetti, Costanza Bonadiman, Roberto Compagnoni,'Luca Nodari, Ingrid

5 Corazzari, Alessandro Pavese

6

7 Highlights:

8

9

- Coexistence of phengite and phlogopite is rare and never observed in Sulu UHP metamorphic terrane.

12

- Exsolving reactions in open system to model a non-isochemical exsolution process.

- Quasi-exsolved phlogopite from disproportion and a supply of elements from HP fluids.

- $\quad P-T$ locus of phengite-phlogopite-quartz-fluid equilibrium close to the metamorphic peak. 
1 Phengite megacryst quasi-exsolving phlogopite, from Sulu Ultra-high Pressure

2 Metamorphic Terrane, Qinglongshan, Donghai County (eastern China): new data for

$5 \quad$ Nadia Curetti ${ }^{\mathrm{a}}$, Costanza Bonadiman ${ }^{\mathrm{b}}$, Roberto Compagnoni ${ }^{\mathrm{a},}$, Luca Nodari ${ }^{\mathrm{c}}$, Ingrid

6 Corazzari $^{\mathrm{d}, \mathrm{e}}$, Alessandro Pavese ${ }^{\mathrm{a}}$

$8 \quad{ }^{a}$ Department of Earth Sciences, University of Turin, 10125 Turin, Italy

$9 \quad{ }^{\mathrm{b}}$ Department of Physics and Earth Sciences, University of Ferrara, 44122 Ferrara, Italy

$10{ }^{\mathrm{c}}$ Institute of Condensed Matter Chemistry and Technology for the Energy- CNR - Padua, Italy

$11{ }^{\mathrm{d}}$ Department of Chemistry, University of Turin, 10125 Turin, Italy

12 e "G. Scansetti" Interdepartmental Center for Studies on Asbestos and Other Toxic Particulates, Turin, Italy.

key-words: phengite and phlogopite micas, exolution reactions, Sulu UHP metamorphic terrane, alkali-alumino-silicate high pressure fluids.

corresponding author: Costanza Bonadiman (bdc @unife.it)

In memory of Prof. Xu Shutong 
Abstract

A large crystal of trigonal phengite (Phe-3T;

$\left.\left.\mathrm{K}_{0.96} \mathrm{Na}_{0.02} \mathrm{Ba}_{0.01}\right)\left(\mathrm{Al}_{1.35} \mathrm{Mg}_{0.40} \mathrm{Fe}^{2+}{ }_{0.11} \mathrm{Fe}^{3+}{ }_{0.13} \mathrm{Ti}_{0.02}\right)_{\Sigma=2.02}\left[\mathrm{Si}_{3.44} \mathrm{Al}_{0.56}\right] \mathrm{O}_{10}(\mathrm{OH})_{2}\right), \quad$ sampled from a phengite+quartz metamorphic vein in the eclogites-bearing rocks of Sulu UHP metamorphic terrane, exhibits unusual thin lamellae of ferrian-aluminian $\begin{array}{lll}\text { trigonal/monoclinic } & \text { phlogopite } & \text { polytypes }\end{array}$ $\left(\mathrm{K}_{0.78} \mathrm{Na}_{0.01}\right)\left(\mathrm{Mg}_{1.48} \mathrm{Fe}^{2+}{ }_{0.39} \mathrm{Fe}^{3+}{ }_{0.45} \mathrm{Al}_{0.30} \mathrm{Ti}_{0.06}\right)_{\Sigma=2.68}\left[\mathrm{Si}_{2.98} \mathrm{Al}_{1.02}\right] \mathrm{O}_{10}\left((\mathrm{OH})_{1.77} \mathrm{~F}_{0.23}\right) ; \quad$ Phl-1M: $\left.\left(\mathrm{K}_{0.85} \mathrm{Ca}_{0.01}\right)\left(\mathrm{Mg}_{1.43} \mathrm{Fe}^{2+}{ }_{0.45} \mathrm{Fe}^{3+}{ }_{0.54} \mathrm{Al}_{0.21} \mathrm{Ti}_{0.06}\right)_{\Sigma=2.69}\left[\mathrm{Si}_{2.88} \mathrm{Al}_{1.12}\right] \mathrm{O}_{10}\left((\mathrm{OH})_{1.99} \mathrm{~F}_{0.01}\right)\right) . \quad$ This assemblage is rarely observed in UHP eclogite-bearing rocks, and has never been reported before in the Sulu UHP metamorphic terrane. A detailed crystal-chemical characterisation of Phe-3T, Phl-3T and Phl-1M allowed the development of a thermodynamic model that estimates the $P-T$ conditions of formation of such an assemblage and helps to understand the relationship between mica polytypes and a quartz dominated (silica oversaturated) system, which characterized the Sulu vein. Phe-3T varies in composition upon approaching Phl-3T/1M, showing a decrease of $\mathrm{Si}$ and $\mathrm{Al}$ and an increase of $\mathrm{Fe}$ and $\mathrm{Mg}$ contents. Observed phlogopites cannot be ascribed to bare exsolving processes, and require the involvement of a non-isochemical reaction, dominated by exsolution (quasi-exsolution process) in combination with a contribution from an "external chemical supplier" (most probably provided by circulating fluids). Mass balance calculations between the mineralogical assemblage of Sulu vein and the solute components of alkali-aluminosilicate high pressure fluids demonstrate that a silicic-type major element composition accounts for a phengite-quartz based rock. The occurrence of phlogopite micas can be explained as an effect of disproportion in combination with supply components, i.e. $\mathrm{Mg}, \mathrm{Al}$ and $\mathrm{K}$, from alkali-alumino-silicate high pressure fluids. 
On the basis of energy modelling of the reaction process from phengite to phlogopite in presence of quartz and a matter exchanger, we determined that such a transformation is weakly dependent on $T$ over the $500-930^{\circ} \mathrm{C}$ thermal range. The intersection of the calculated $P-T$ assemblage equilibrium curve with the country rock $P-T$ metamorphic path occurs at $P \sim 2.4 \pm 0.2 \mathrm{GPa}$ and $T \sim 700^{\circ} \mathrm{C}$, thus reflecting an early stage of exhumation, close to the metamorphic peak of the Sulu UHP terrane.

\section{Introduction}

During prograde metamorphism, veins promoted by the availability of the fluid released by the dehydration reactions accompanying temperature (and pressure) increase are ubiquitous (Cong et al. 1994; Zheng et al., 2005). In case of decarbonation reactions, $\mathrm{CO}_{2}$ also occurs in the fluid phase and carbonate minerals may form in place of or together with silicates. The vein mineral assemblage, which reflects the occurring $P-T-X$ conditions at the time of its formation, is useful to infer the metamorphic path experienced by a rock during the whole tectonic evolution. Usually, a close relationship exists between the country rock and the mineralogical composition of the metamorphic vein: e.g., in lowgrade metapelites, most metamorphic veins consist of quartz and/or low-temperature minerals such as Fe-rich chlorite and epidote (Hermann and Rubatto, 2009).

Conversely to a widespread opinion that eclogites form at dry conditions or at very low water activity, metamorphic veins involving fluids are not unusual in the HP (high pressure) and UHP (ultra-high pressure) eclogite-facies (Poli and Fumagalli, 2003). For example, in eclogites quartz-rutile veins are ubiquitous, and they were used to estimate the metamorphic temperatures by means of the oxygen isotopes partitioning (e.g., Desmons and O’Neill, 1978). 
Good examples of such HP veins in subducted continental crust are found in the "Eclogitic Micaschist Complex" of the Sesia Zone, Western Alps, where quartz veins may include rutile crystals, more than $20 \mathrm{~cm}$ long (Compagnoni et al., 2014 and references therein). In the same unit, a metamorphic vein was found, 1-2 $\mathrm{m}$ thick and more than $80 \mathrm{~m}$ long, mainly consisting of phengite and minor quartz: the phengite flakes, which are up to $30 \mathrm{~cm}$ wide, show a unique oscillatory zoning and the coexistence of $3 T$ and $2 M_{1}$ polytypes, and no evidence of phlogopite polytypes (Ivaldi et al., 2001).

In the HP/UHP eclogites of the Dabie-Sulu orogenic belt, in addition to the ubiquitous quartz-rutile veins, quartz+zoisite+kyanite veins were found in the Zhu-Jia-Chong eclogite body, where the vein minerals may also attain a pegmatoid size (Castelli et al., 1998). It was proposed that such veins were formed in a closed system during the breakdown of lawsonite which resulted in a kyanite +zoisite +hydrous fluid, either before peak metamorphic conditions (Castelli et al., 1998) or during exhumation (Li et al., 2005).

These metamorphic veins are quite different from veins formed by partial melting during exhumation, which are characterised by a mineral assemblage that reflects the minimum melting granite, i.e. the ubiquitous presence of feldspars and mineral grain-size of the order of millimetres (Deng et al., 2017 and references therein).

The phengite specimen under investigation was sampled from a phengite+quartz metamorphic vein, excavated at Qinglongshan, very close to the G30 Lianhuo Expressway, crossing the Donghai County (eastern China). The phengite was collected in a small dump derived from a vertical shaft, excavated in the eclogites-bearing rocks of Sulu UHP metamorphic terrane to mine pure quartz (Fig. 1).

The peak conditions of the UHP metamorphism of the Qinglongshan rocks were estimated at $T \sim 700-800^{\circ} \mathrm{C}$ and $P>2.8 \mathrm{GPa}$ (Hirajima and Nakamura, 2003; Liu et al., 2015; Xu et al., 
2012; Zhang et al., 1995) and several $P$-T paths have been suggested (e.g., Ferrando et al., 2005; Frezzotti et al., 2007).

The phengite sample consists of a single undeformed platy crystal, about $520 \mathrm{~cm}^{3}$ in volume, with a dusky yellowish green colour (Rock Colour Chart, 1991), and it shows the unusual thin lamellae of Fe-phlogopite.

The coexistence of phengite and phlogopite is rarely observed in UHP eclogite-bearing rocks (e.g., Eastern Alps; Eclogite Zone, Tauern, Austria; Frank et al.,1986) and, to the authors' knowledge, has never been reported from Sulu UHP terrane.

The condition and nature of the reactions that lead to the equilibrium of phengite with phlogopite (Zanazzi and Pavese, 2002) upon decreasing pressure are still poorly defined. Melting experiments, conducted on the synthetic $\mathrm{K}_{2} \mathrm{O}-\mathrm{MgO}-\mathrm{Al}_{2} \mathrm{O}_{3}-\mathrm{SiO}_{2}-\mathrm{H}_{2} \mathrm{O}$ (KMASH) system (Massonne and Szpurka, 1997; Thomsen and Schmidt, 2008) and on natural carbonate-bearing eclogites (Droop et al., 1990; Zhang et al., 1995), suggest that a silicate melt at $P>2 \mathrm{kbar}$ and $600^{\circ}<T<700^{\circ} \mathrm{C}$ produces volatile-rich phases, among which phengite plays a relevant role as potassic mineral (Hermann and Green, 2001; Massonne and Szpurka, 1997; Schmidt and Poli, 1998;; Schmidt et al., 2004).

In view of this, the finding in a quartz+mica assemblage of a large crystal of phengite together with seemingly exsolved phlogopite motivated the present investigation. Note that, an exsolving process in a closed system alone cannot account for the coexistence of phengite and phlogopite, and complex metasomatic reactions involving fluids are also to be assumed. The aim of this work is to provide a thermodynamic model that estimates the $P-T$ of formation, starting from a detailed crystal-chemical characterisation of the involved micas.

Phengites $(P h e)$ are dioctahedral micas (ideal composition: $\mathrm{KAl}_{2-\mathrm{x}}\left(\mathrm{Fe}, \mathrm{Mg}_{\mathrm{x}}\left[\mathrm{Si}_{3+\mathrm{x}} \mathrm{Al}_{1-}\right.\right.$ 
$\left.115{ }_{\mathrm{x}} \mathrm{JO}_{10}(\mathrm{OH})_{2}\right)$ that usually occur in nature as $2 M_{1}$ (more abundant) and $3 T$ polytypes (S.G. $C 2 / c$ and $P 3_{1} 12$, respectively). Several $3 T$ structures were refined and reported in literature (Amisano-Canesi at al., 1994; Ivaldi et al., 200; Pavese et al., 1997, 1999, 2000, 2003a; Smyth et al., 2000; Weiss et al., 1993), although special attention must be paid to the reliability of the occupancy factors (Pavese and Diella, 2013). Because of its occurrence in high-pressure metamorphic rocks, the $3 T$ polytype is thought to be more suitable for high $P$ conditions than $2 M_{1}$. The $3 T$ polytype presents two independent occupied octahedral-sites (Ferraris et al., 1995; Ferraris and Ivaldi, 2002) while the $2 M_{1}$ only shows one. The $3 T$ to $2 M_{1}$ transition is supposed to take place upon decreasing the $P / T$ ratio (Ivaldi et al., 2001; Sassi et al., 1994). The occurrence of one polytype instead of the other is useful in constraining the pressure-temperature conditions of formation.

In the metamorphic dioctahedral micas, the ${ }^{\mathrm{IV}} \mathrm{Si}$ content increases with increasing crystallisation pressure. Single crystals of quartz platelets, 100-700 Å thick, were observed, along with talc, in a phengite coming from the UHP Brossasco-Isasca Unit of southern Dora-Maira Massif, Western Italian Alps (Ferraris et al., 2000). Their occurrence was related to an intra-crystalline re-organisation during decompression of the original phengites.

Phlogopites $(P h l)$ are trioctahedral micas (ideal composition $\mathrm{KMg}_{3}\left[\mathrm{Al} \mathrm{Si}_{3}\right] \mathrm{O}_{10}(\mathrm{OH})_{2}$ ) that usually crystallise as $1 M($ S.G. $C 2 / m)$ and rarely as $3 T$ (S.G. $\left.P 3_{1} 12\right)$ polytypes. Only two phlogopites $3 T$ were refined and reported in literature: the first one comes from Traversella - Western Alps (Gatta et al., 2011) and the second from Kasenyi - Uganda (Schingaro et al., 2013).

A miscibility gap between dioctahedral and trioctahedral micas is known. Lester (1946) and Gresen et al. (1971) described exsolutions in micas coming from Mitchell Creek 
139 (Georgia, USA). The quoted authors observed unusual and pyramidal intergrowths of biotite in muscovite. Two instances of transmission electron microscopy investigations on trioctahedral exsolutions in magmatic muscovite $2 M_{1}$ were reported: very small exsolutions ( 10nm scale) in muscovite from Lawler Peak granite -Arizona (Ferrow et al., $1990)$ and ferro-aluminian phlogopitic lamellae ( $1 \mathrm{~mm}$ scale) in muscovite from pegmatite outcropping near Gorduno -Switzerland (Ferraris et al., 2001). Experimental studies in the system $\mathrm{K}_{2} \mathrm{O}-\mathrm{M}^{2+}-\mathrm{Al}_{2} \mathrm{O}_{3}-\mathrm{SiO}_{2}-\mathrm{H}_{2} \mathrm{O} \pm(\mathrm{HF})$ with $\mathrm{M}^{2+}=\mathrm{Mg}^{2+}$ or $\mathrm{Fe}^{2+}$ at $P \sim 2 \mathrm{kbar}$ and variable $T\left(200-700^{\circ} \mathrm{C}\right)$ showed a relevant dependence of the solid solution stability on temperature (Monier and Robert, 1986a, 1986b).

Understanding the principles underlying the coexistence of the observed phengite and phlogopite in a quartz dominated (silica oversaturated) mineral assemblage of the Sulu vein, will shed light on the "peculiar" $P-T-X$ conditions and evolution of the process involved in their formation.

\section{Materials and Methods}

\subsection{Sample Description}

The original specimen is a large, flat, regular flake (about $20 \mathrm{~cm} \times 15 \mathrm{~cm} \times 2 \mathrm{~cm}$ ) of a seemingly hosting phengite mica, characterised by a homogeneous deep green colour. Optical observations and single crystal X-ray rotation photos were performed on several samples extracted from different regions of the phengite mica. They confirmed an overall homogeneous trigonal symmetry of the phengite mica (Fig. 2).

In some areas of the sample, especially near the margins of the flake, associations of quartz and brown micas were observed (Fig. 3). Their nucleation and growth are clearly 
successive to the hosting phengite crystallisation, because of the preserved iso-orientation of the (001) plane in both hosted- and hosting-micas. This suggests the occurrence of exsolving processes, with the contribution from an "external chemical supplier" (most probably ascribable to fluid circulation). Therefore, the term "quasi-exsolution" is used hereafter to address a non-isochemical exsolution process. Such quasi-exsolved micas have sub-millimetre extension and micrometre thickness; their shape can be euhedral and pyramidal (Lester, 1946. Fig. 2), or irregular (Fig. 3). Several quasi-exsolved mica samples were extracted and tested by single crystal X-ray rotation photos. Most of the specimens are trigonal, and only a few present monoclinic symmetry.

\subsection{Analytical methods}

A fragment of the original mica-matrix sample was grounded to carry out preliminary $\mathrm{X}$ ray powder diffraction characterisations. The measurements were performed by a HuberGuinier 670 camera, $\mathrm{CuK} \alpha$ radiation, scan range $2^{\circ}<2 \theta<70^{\circ}$ and the diffraction patterns were processed by the GSAS Software Package.

The combination of X-ray powder diffraction, optical observations and chemical composition from micro-analyses, revealed the simultaneous occurrence of a major phengite (hereafter Phe-3T) and two minor phlogopite polytypes (Phl-3T and Phl-1M, for trigonal and monoclinic quasi-exsolved phlogopites, respectively). Single crystal specimens were separated for X-ray diffraction, which was performed at room temperature using MoK $\alpha$ radiation by both a Siemens P4 diffractometer, equipped with a point detector (University of Turin), and a Gemini R Ultra X-ray diffractometer, equipped with a Ruby CCD detector (CrisDi Interdepartmental Center for Crystallography, University of Turin). The former was used to measure lattice parameters of the samples under investigation; the latter to record diffraction intensities. Because of the limited crystal thickness, the quasi- 
exsolved crystals provided a comparatively small number of $h k l$-reflections. Structure refinements have been performed using both SHELXL-97 package (Sheldrick, 1997) and Jana2006 software (Petricek et al., 2014). Phl-3T data allowed a structure refinement using isotropic atomic displacement parameters, only. Single crystal X-ray diffraction experimental setup, overall refinement conditions and lattice parameters of each phase are reported in Table S1.

Four fragments from different areas of the original hosting-phengite flake were embedded in epoxy resin and analysed to determine their for chemical composition. Major element compositions were obtained by an ARL-SEMQ electron microprobe analyser (EMPA) equipped with wavelength- and energy-dispersive spectrometers (University of Modena and Reggio Emilia). The following operating conditions were set: $15 \mathrm{kV}$ and $20 \mathrm{nA}$ beam current. Quartz $(\mathrm{Si})$, corundum $(\mathrm{Al})$, periclase $(\mathrm{Mg})$, magnetite $(\mathrm{Fe})$, rhodonite $(\mathrm{Mn})$, grossular $(\mathrm{Ca})$, rutile $(\mathrm{Ti})$, chromium oxide $(\mathrm{Cr})$, vanadinite $(\mathrm{V})$, albite $(\mathrm{Na})$, apatite $(\mathrm{P})$ have been used as standards for the elements in parentheses.

Mössbauer spectroscopic analyses were performed on the Phe-3T sample in order to quantify $\mathrm{Fe}^{2+}$ and $\mathrm{Fe}^{3+}$. The spectrum was collected at room temperature on about $80 \mathrm{mg}$ of powdered sample (Fig. 4), by a conventional constant acceleration spectrometer, using a rhodium matrix ${ }^{57}$ Co source, nominal strength $1850 \mathrm{mBq}$ (University of Padua). To reduce the crystal iso-orientation, a "magic angle" setting was used $\left(54^{\circ}\right.$ between the incident beam and the sample plain). The hyperfine parameters isomer shift $(\delta)$, quadrupole splitting $(\Delta)$, full linewidth at half maximum $(\Gamma)$, were expressed in mms -1 while the relative area (A) in \%. The parameters were obtained by means of standard least-squares minimiaation techniques. The spectra were fitted to Lorentzian line shapes with the minimum number of doublets. $\delta$ is quoted to $\alpha$-Fe, using a 4-lines calibration. 
The water content was assessed by means of thermogravimetric analyses (TGA). TG

213 analyses were carried out under dynamic nitrogen atmosphere $\left(35 \mathrm{~mL} \mathrm{~min}^{-1}\right)$ by a Pyris 1

214 ultra-micro-balance - Perkin Elmer. The sample was heated in the temperature range 30-

$2151000{ }^{\circ} \mathrm{C}$ (heating rate $20{ }^{\circ} \mathrm{C} \min ^{-1}$ ) and an overall weight loss of $4.5 \%$ was observed. A

216 first process, observed between 30 and $180{ }^{\circ} \mathrm{C}$, was responsible for a weight loss of $0.5 \%$

217 and was attributed to the desorption of physisorbed water. From $180^{\circ} \mathrm{C}$ the sample 218 continuously lost weight up to $980{ }^{\circ} \mathrm{C}$ due to a not well defined process which was 219 responsible for a weight loss of $4 \%$ and was reasonably attributed to the evolution of 220 structural water.

\section{Results}

Phe-3T and quasi-exsolved Phl-phases major element compositions are reported in Table

1, whereas the doublets best fit parameters of Mössbauer patterns are listed in Table S2.

On the basis of EMPA and Mössbauer analyses, the chemical formula unit of Phe-3T (calculated according to 22 negative charges) is:

$\left(\mathrm{K}_{0.96} \mathrm{Na}_{0.02} \mathrm{Ba}_{0.01}\right)\left(\mathrm{Al}_{1.35} \mathrm{Mg}_{0.40} \mathrm{Fe}^{2+}{ }_{0.11} \mathrm{Fe}^{3+}{ }_{0.13} \mathrm{Ti}_{0.02}\right)_{\Sigma=2.02}\left[\mathrm{Si}_{3.44} \mathrm{Al}_{0.56}\right] \mathrm{O}_{10}(\mathrm{OH})_{2}$.

Quantitative chemical analyses performed on the Phl-3T specimens provided the following chemical formula unit:

$\left(\mathrm{K}_{0.78} \mathrm{Na}_{0.01}\right)\left(\mathrm{Mg}_{1.48} \mathrm{Fe}^{2+}{ }_{0.39} \mathrm{Fe}^{3+}{ }_{0.45} \mathrm{Al}_{0.30} \mathrm{Ti}_{0.06}\right)_{\Sigma=2.68}\left[\mathrm{Si}_{2.98} \mathrm{Al}_{1.02}\right] \mathrm{O}_{10}\left((\mathrm{OH})_{1.77} \mathrm{~F}_{0.23}\right)$.

Comparing the two compositions, Phl-3T is consistently richer in Fe and $\mathrm{Mg}$ than Phe-3T,

233 but the ${ }^{\mathrm{VI}} \mathrm{Mg} /{ }^{\mathrm{VI}} \mathrm{Fe}$ ratio in the two phases is similar $\left[\left({ }^{\mathrm{VI}} \mathrm{Mg} /{ }^{\mathrm{VI}} \mathrm{Fe}\right){ }_{\text {Phe-3T }}=1.70\right.$, $\left.234 \quad\left({ }^{\mathrm{VI}} \mathrm{Mg} /{ }^{\mathrm{VI}} \mathrm{Fe}\right)_{P h l-3 T}=1.63\right]$.

235 The analyses on the quasi-exsolved monoclinic polytype, Phl-1M, provided a chemical 
composition very close to the trigonal polytype's:

$\left(\mathrm{K}_{0.85} \mathrm{Ca}_{0.01}\right)\left(\mathrm{Mg}_{1.43} \mathrm{Fe}^{2+}{ }_{0.45} \mathrm{Fe}^{3+}{ }_{0.54} \mathrm{Al}_{0.21} \mathrm{Ti}_{0.06}\right)_{\Sigma=2.69}\left[\mathrm{Si}_{2.88} \mathrm{Al}_{1.12}\right] \mathrm{O}_{10}\left((\mathrm{OH})_{1.99} \mathrm{~F}_{0.01}\right)$.

Changes of composition from Phe-3T to its phlogopite quasi-exsolved products were measured along radial directions departing from the separation edge (Fig. 5). A shell with variable width $(\sim 300-500 \mu \mathrm{m})$ and zoned composition was found: approaching the quasiexsolved phases, $\mathrm{Si}$ and $\mathrm{Al}$ decrease, while $\mathrm{Fe}$ and $\mathrm{Mg}$ increase (Table 1; Fig.5). Midway along the transition region from phengite to phlogopite, the following approximated composition occurs:

$\left(\mathrm{K}_{0.89} \mathrm{Na}_{0.02}\right)\left(\mathrm{Al}_{1.24} \mathrm{Fe}_{0.52} \mathrm{Mg}_{0.54} \mathrm{Ti}_{0.02}\right)_{\Sigma=2.32}\left[\mathrm{Si}_{3.16} \mathrm{Al}_{0.84}\right] \mathrm{O}_{10}(\mathrm{OH})_{2}$.

The compositions of Phl-1M and Phl-3T correspond in micas' nomenclature (Rieder et al., 1998) to "ferrian aluminian phlogopite"; abbreviated to "phlogopite" in the rest of the study.

\subsection{Phe-3T and Phl-polytypes}

\subsubsection{Phe-3T}

The average distances $\langle\mathrm{T} 1-\mathrm{O}\rangle$ and $\langle\mathrm{T} 2-\mathrm{O}\rangle$ are equal (1.631(1) $\AA$; Tables S3 and S4) and in agreement with literature values. The ditrigonal rotation (Table S5) of the tetrahedral sheet $\left(\sim 48^{\circ}\right)$ is in keeping with a HP regime (Curetti et al., 2008).

The average distances $\langle$ M2-O $\rangle$ and $\langle$ M3-O $\rangle$ are meaningfully different $(1.958(1) \AA$ and 1.972(1) ̊̊, respectively) and indicate a partial octahedral ordering of large cations in M3, although the refined number of electrons (14.3(2) $e$ and 14.7(2) $e$ in M2 and M3, respectively; Table S3) cannot confirm this inference from bond-lengths.

Mössbauer spectroscopy suggests partial octahedral ordering of iron: (i) $\mathrm{Fe}^{3+}$ absorption is 
modelled by only one doublet, which suggest that the trivalent iron is completely ordered in one octahedron (0.13 $\mathrm{Fe}^{3+}$ a.p.f.u.); (ii) $\mathrm{Fe}^{2+}$ absorption is fitted by two doublets, each corresponding to one site (0.05 and $0.06 \mathrm{Fe}^{2+}$ a.p.f.u.). Several Mössbauer analyses on dioctahedral micas $2 M_{1}$ were reported in literature (Aldrige et al., 1987; Finch et al., 1982; Goodman, 1976; Shabani et al., 1998). The patterns usually show two different doublets for $\mathrm{Fe}^{2+}$, even if they are expected to have only one occupied symmetry independent octahedral site. To explain the unexpected second doublet (very weak and corresponding to 0.03-0.04 $\mathrm{Fe}^{2+}$ a.p.f.u., at most) the quoted authors assumed a partial occupancy of the M1trans site. The $3 T$ polytype has two independent octahedral sites (M2 and M3) and the two $\mathrm{Fe}^{2+}$ doublets can be assigned without resorting to the M1 empty site (Merli et al., 2009; Pavese et al., 2000; Pavese et al., 2001;). In fact, partial and very low M1 occupancy is suggested by both chemical analyses (octahedral cations sum $=2.02$ a.p.f.u.) and structural refinement (0.86 $e$ in the Fourier difference, 0.3(1) $e$ refined), though the electron content corresponding to each Mössbauer doublet is too high in comparison with the M1 refined occupancy (0.05 a.p.f.u. corresponding to about $1.3 e$ ). Mössbauer spectroscopy is not able to univocally associate iron doublets to specific sites, however its combination with structure refinements allows one to infer a partially ordered distribution of $\mathrm{Fe}, \mathrm{Al}$ and $\mathrm{Mg}$. The M1 octahedral site is almost completely empty. The $\mathrm{H}$ atom position was determined by the Fourier Difference and refined; the O-H distance is 0.80(4) $\AA$ and the angle between O-H bond and ( $\left(\begin{array}{lll}0 & 0 & 1\end{array}\right)$ plane is $\sim 6.55^{\circ}$.

\subsubsection{Phl-3T}

Several crystals of phlogopite $3 T$ were sampled from the hosting phengite Phe-3T, but only a few were suitable for measurements and structure refinements. Such specimens are about 
$200-400 \mu \mathrm{m}$ in length and width, and very thin $(<50 \mu \mathrm{m})$. A modest number of reflections were measured for $P h l-3 T$ and the structural refined parameters show large uncertainties, as shown in the figure of merit reported in Table 1, i.e. $R\left[\left|\mathrm{~F}_{\mathrm{o}}\right|>4 \sigma\left(\left|\mathrm{F}_{\mathrm{o}}\right|\right)\right]=8.50 \%$. Therefore structure constraints were introduced in the refinement strategy. The atomic displacement parameters have been constrained as follows: $\mathrm{U}_{\text {iso }}(\mathrm{M} 1)=\mathrm{U}_{\text {iso }}(\mathrm{M} 2)=\mathrm{U}_{\text {iso }}(\mathrm{M} 3), \mathrm{U}_{\text {iso }}(\mathrm{T} 1)=$ $\mathrm{U}_{\text {iso }}(\mathrm{T} 2), \mathrm{U}_{\text {iso }}(\mathrm{O} 1)=\mathrm{U}_{\text {iso }}(\mathrm{O} 2)=\mathrm{U}_{\text {iso }}(\mathrm{O} 3)=\mathrm{U}_{\text {iso }}(\mathrm{O} 4)=\mathrm{U}_{\text {iso }}(\mathrm{O} 5)=\mathrm{U}_{\text {iso }}(\mathrm{O} 6)$ (Table 4). Conversely, the fractional coordinate distances were refined without any constraint, and the cation-anion distances were determined accordingly.

The structural results can be compared with those of the trigonal phlogopite samples from Traversella $(P h l-\mathrm{TR})$ and from Uganda $(P h l-\mathrm{UG})$. In $P h l$-TR $<\mathrm{M} 1-\mathrm{O}>$ is $2.079 \AA$, and 2.072(6) $\AA$ in Phl-UG. In both samples, <M1-O>s are not significantly different from $\langle\mathrm{M} 2-\mathrm{O}\rangle$ and $\langle\mathrm{M} 3-\mathrm{O}\rangle$. Conversely, the trigonal phlogopite sample investigated here, exhibits $\langle\mathrm{M} 1-\mathrm{O}\rangle$ of $2.245(3) \AA$, some $10 \%$ longer than $\langle\mathrm{M} 2-\mathrm{O}\rangle=1.991$ (8) $\AA$ and $\langle\mathrm{M} 3-$ $\mathrm{O}>=2.052(8) \AA$ (Table S4).

The occupancy factors of Fe-Al-Mg-Si in the tetrahedral and octahedral sites were not refined and the cations were arranged according to a completely disordered distribution. Only the number of electrons in the interlayer site was refined, as 16.9(2) $e$.

Comparing the distortion parameters (Table S5) with those reported for Phl-TR/UG, $P h l$ $3 T$ is more strained. Such an aspect is more marked in Phl-UG. The major distortions are not related to bond lengths, but mainly to angular values, thus suggesting that the structure strain is probably due to the $P h l-3 T$ 's growth process, which took place as a progressive substitution of the pre-existing framework of Phe-3T. 


\subsubsection{Phl-1M}

Only a few specimens of monoclinic quasi-exsolved phase were found in the hosting phengite. Using the largest one we performed single crystal X-ray diffraction experiments with a satisfactory number of reflections. The structure refinement in the S.G. $C 2 / m$ converged to $\mathrm{R} \sim 4.78 \%$ (Table $\mathrm{S} 3$ ).

The cell parameters $\left(a=5.3195(13) \AA, b=9.2117(12) \AA, c=10.210(3) \AA, \beta=100.04(2)^{\circ}\right.$, $V=492.7(2) \AA^{3}$; Table S4) are in excellent agreement with the ones of Phl-3T $(a=$ 5.318(1) $\left.\AA, c=30.21(2) \AA ; c_{(1 \mathrm{M})} \times \operatorname{sen} \beta(1 \mathrm{M})=30.16 \AA\right)$.

Average bond distances $\langle\mathrm{T}-\mathrm{O}\rangle_{1 \mathrm{M}}=1.652(1) \AA,\langle\mathrm{M}-\mathrm{O}\rangle_{1 \mathrm{M}}=2.074(1) \AA$ and $\langle\mathrm{I}-\mathrm{O}\rangle_{1 \mathrm{M}}=$ 3.159(1) $\AA$ are very similar to the corresponding values in Phl-3T sample (Tables S3 and S4). The two M-O distances are meaningfully different from one another $(\langle\mathrm{M} 1-\mathrm{O}\rangle=$ 2.088(1); $\langle\mathrm{M} 2-\mathrm{O}\rangle=2.061(1) \AA)$, but the refined electron content $(14.17(14)$ and 14.18(12) $e$ for M1 and M2, respectively) does not indicate any cation order.

Phl- $1 M$ yields bond-lengths, bond-angles and distortion parameters $\left(\alpha=8.00^{\circ}, \Delta \mathrm{z}=0.01 \AA\right.$; $\Delta_{\mathrm{TM}}=0.44 \AA, \mathrm{BLD}_{\mathrm{M} 1}=0.76 \%, \mathrm{BLD}_{\mathrm{M} 2}=0.80 \%, \mathrm{~J}_{\mathrm{M} 1}=0.00^{\circ}$ and $\mathrm{J}_{\mathrm{M} 2}=0.88^{\circ} ;$ Table S5) in agreement with those reported in literature on phlogopite $1 M$ (Brigatti and Guggenheim, 2002).

\section{Discussion}

\subsection{Mass balance calculation}

The rock containing the studied micas and quartz is a thick metamorphic vein, similar to those commonly observed in the Sulu UHP terrane. A not-weighted mass balance calculation (Wright and Doherty, 1970) was used to provide the best match between the 
sampled mineralogical assemblage and fluid alkali-alumino-silicate components that mirror the bulk rock averaged compositions of the Sulu-vein $(A S V)$, reduced to an anhydrous major oxides system (Table 2):

$x_{1} P h e-3 T+x_{2}$ quartz $+x_{3} P h l-3 T+x_{4} P h l-1 M+x_{5} \mathrm{~K}$-feldspar $=1 A S V$

where $x_{i}$ represents the $i$-phase proportion. The solution is (least square residuum, $r^{2}=0.8$ ):

0.574 Phe-3T +0.488 quartz $+(-0.049) P h l-3 T+(-0.002) P h l-1 M+(-0.001) \mathrm{K}-$ feldspar $=1$ $A S V$

Eq.(2) demonstrates that $A S V$ accounts for a phengite-quartz based rock and the occurrence of phlogopite micas can be explained as an effect of disproportion in combination with a supply of elements, i.e. $\mathrm{Mg}, \mathrm{Al}$ and $\mathrm{K}$, most probably solute components of alkali-aluminosilicate aqueous solutions at high pressure rock-fluid interactions.

Such results agree with the observed petrographic characteristics of the vein fragment from which the studied micas were extracted: (1) phengite and quartz are comparably proportioned in the rock; (2) the negative phase proportion coefficients suggest that phlogopites are per force scarce and only occur as quasi-exsolved phases, in combination with an elemental supply from alkali-alumino-silicate high pressure fluids; (3) K-feldspar is modally absent in the fragment, as the negligible resulting negative proportion (i.e. 0.001) suggests.

\section{$4.2 \quad P-T-X$ Equilibrium phases in an open system}

The coexistence of $P h e-3 T, P h l-3 T$ and $P h l-1 M$ micas cannot be reduced to bare exsolving reactions in a closed system and a contribution from an "external chemical supplier", i.e. a "reservoir", has to be taken into account (eq.(2)). Therefore, the reactions were modelled 
in terms of an open system. Following Merli et al. (2017), the "reservoir" is now seen as a matter exchanger, whose composition, addressed by $\operatorname{Res}(\mathrm{A} / \mathrm{B})$, encompasses all the potential solids and fluids taking part in the petrogenetic reactions, but micas and quartz. $\mathrm{A} / \mathrm{B}$ are used to indicate a specific chemical condition of the reservoir. In this case, we modelled the reaction process from phengite to phlogopite with the following transformation:

phengite $+\operatorname{Res}(\mathrm{A})=$ phlogopite $+\lambda$ quartz $+\operatorname{Res}(\mathrm{B})$

where $\lambda$ is related to the amount of quartz exsolved from the reacting phengite, i.e. $\lambda \approx 0.46$.

The equilibrium conditions of the assemblage require that

$$
\begin{gathered}
\Delta G=G(\text { phengite })+G[\operatorname{Res}(\mathrm{A})]-G(\text { phlogopite })-G[\operatorname{Res}(\mathrm{B})]-\lambda G(\text { quartz })= \\
G(\text { phengite })-G(\text { phlogopite })-\lambda G(\text { quartz })+\{G[\operatorname{Res}(\mathrm{A})]-G[\operatorname{Res}(\mathrm{B})]\}= \\
G(\text { phengite })-G(\text { phlogopite })-\lambda G(\text { quartz })+\delta G[\operatorname{Res}]=0,
\end{gathered}
$$

where $G$ is the molar Gibbs energy of a given phase, i.e. its chemical potential, and $\delta G[R e s]$ is the molar Gibbs energy difference between $\operatorname{Res}(\mathrm{A})$ and $\operatorname{Res}(\mathrm{B})$. Phengite and phlogopite refer to $P h e-3 T$ and $P h l-3 T$, respectively.

The Gibbs energy of a phase at given $P-T$ conditions can be determined by two distinct integrations, one along an isobar at $P_{0}$ and the other along an isotherm at $T$, i.e.

$G(P, T)=G\left(P_{0}, T_{0}\right)-\int_{T_{0}}^{T} S\left(P_{0}, T^{\prime}\right) d T^{\prime}+\int_{P_{0}}^{P} V\left(P^{\prime}, T\right) d P^{\prime}$

where $P_{0}$ and $T_{0}$ are in general reference pressure and temperature (for explicit calculations refer to Pavese and Diella, 2007), here corresponding to room pressure and temperature. Equation (5) can be written as

$\Delta G(P, T)=\Delta G\left(P_{0}, T_{0}\right)+\Delta I_{T-T_{0}}+\Delta I_{T-T_{0}, \text { config }}+\Delta I_{P-P_{0}}$ where $\Delta G\left(P_{0}, T_{0}\right)$ is the formation energy with respect to the standard state of the constituent oxides. $\Delta I_{P-P_{0}}$ is due to the solid phases of eq. (4), i.e. micas and quartz, and it 
can be determined by means of the equations of state of the involved minerals. We used a third order Birch-Murnaghan $P-V-T$ relationship and thermo-elastic parameters from Amisano-Canesi et al. (1994); Angel et al. (1997); Chon et al. (2003, 2006 ); Comodi et al. (1999); Curetti et al. (2006); Gatta et al. (2009, 2011), Gemmi et al. (2008). Hazen and Finger (1978); Russell and Guggenheim (1999); Takeda and Morosin (1975) and Ventruti et al. (2009).

$\Delta G\left(P_{0}, T_{0}\right)+I_{T-T_{0}}$ were estimated by the reaction:

$\frac{1}{2}$ muscovite $+\frac{1}{4}$ celadonite $+\frac{1}{4} \mathrm{Fe}-$ celadonite +1.75 periclase +0.75 wüstite $=$ $\frac{2}{3}$ phlogopite $+\frac{1}{3}$ annite $+\frac{1}{2}$ corundum $+\frac{1}{2}$ quartz

taking the Gibbs energy of formation and heat capacity at constant pressure from Holland and Powell (1998). The $\Delta G\left(P_{0}, T_{0}\right)+I_{T-T_{0}}$ is modest and weakly dependent on $T$ in the investigated $770-1200 \mathrm{~K}$ thermal range. In was therefore approximated by a constant as large as $13 \mathrm{~kJ} / \mathrm{mol}$. However, taking into account the high degree of approximation, we assumed a confidence range from 10 to $15 \mathrm{~kJ} / \mathrm{mol}$, and explored its limits. Lastly, $\Delta I_{T-T_{0}, \text { config }}$ is due to the configuration contribution to entropy, $S_{\text {config }}$, which is calculated as follows:

$$
S_{\text {config }}=-\mathrm{R} \sum_{j=1}^{\text {sites }} \sum_{\alpha=1}^{\text {chemical species }} p_{j, \alpha} \ln \left(p_{j, \alpha}\right)
$$

where $\mathrm{R}$ is the universal gas constant and $p_{j, \alpha}$ is the occupancy factor of the $\alpha$-species at the $j^{\text {th }}$-sites. In figure 6 we display the $P-T$ loci $\left(\mathrm{GPa}\right.$ and $\left.{ }^{\circ} \mathrm{C}\right)$ of equilibrium for reaction (4), with $\Delta G\left(P_{0}, T_{0}\right)+I_{T-T_{0}}$ equal to 10 and $15 \mathrm{~kJ} / \mathrm{mol}$, respectively.

The intersection between the equilibrium $P-T$ locus and the supposed $P-T$ metamorphic path of OH-rich quartzite from Sulu UHP terrane from Frezzotti et al. (2007) occurs at $P \approx$ 2.4 $\pm 0.2 \mathrm{GPa}$ and $T \approx 700{ }^{\circ} \mathrm{C}$. Such a result is consistent with the observation of Hermann 
and Green (2001), if the phengite existence curve of the quoted authors is extrapolated to $700{ }^{\circ} \mathrm{C}$.

On the basis of petrological data, stable isotope geothermometry and theoretical phase relationships of quartzites from Sulu terrane, the UHP fluids composition estimated by Frezzotti et al. (2007) is an intermediate alkali-alumino-silicate aqueous solutions $\left(\mathrm{H}_{2} \mathrm{O}\right.$ $\sim 50 \mathrm{wt} \%$ ), that constrains the metamorphic peak at $P \sim 3.5 \mathrm{PGa}$ and $T \sim 780{ }^{\circ} \mathrm{C}$.

The obvious compositional similarity between the quartzites investigated by Frezzotti et al. (2007) and the Sulu vein of this study allowed us to state that the calculated P-T conditions for phlogopite growth in a $\mathrm{SiO}_{2}$ oversaturated system indicate at a region that reflects early stages of exhumation, close to the metamorphic peak (Fig. 6).

\section{Conclusions}

The main purpose of this work was to study the rare coexistence of dioctahedral mica and trioctahedral quasi-exsolutions observed in a thick quartz+phengite metamorphic vein found in the northern part of Sulu UHP metamorphic terrane, of Donghai County (eastern China).

The process leading to such an assemblage is described as a "quasi-exsolution" process and it is constituted by non-isochemical exsolution . The composition change is due to an external supplier.

The reaction process from phengite to phlogopite favours /requires the exsolution of quartz. Because of the trigonal structure provided from phengite, the quasi-exsolved phlogopite crystallised as $3 T$-polytype, which is unusual for trioctahedral micas.

Mass balance calculations suggest that the phengite-quartz based rock and the occurrence of phlogopite micas can be explained as an effect of disproportion in combination with a 
supply of elements, i.e. $\mathrm{Mg}, \mathrm{Al}$ and $\mathrm{K}$, from alkali-alumino-silicate high pressure fluids, that mirror the bulk Sulu vein composition.

The calculated equilibrium $P-T$ locus of phengite-phlogopite-quartz reaction intersects the $P-T$ metamorphic path at $P \approx 2.4 \pm 0.2 \mathrm{GPa}$ and $T \approx 700{ }^{\circ} \mathrm{C}$, indicating an early stage of exhumation, close to the metamorphic peak of the Sulu UHP terrane.

\section{Acknowledgements}

The studied phengite was collected in 2000, during a field expedition in the Sulu orogene, organised by Prof. Xu Shutong in the framework of a Chinese-Italian cooperation project (R.C The authors thank the Editor Marco Scmbelluri, Patrizia Fumagalli and anonymous reviewer for their positive comments. The authors would like to thank the "Compagnia di San Paolo" of Turin, Italy, for supporting the TGA measurements. L.N would like to thank the Department of Chemical Science, University of Padua, for allowing the free use of Mössbauer spectrometer.

The paper benefited of the English language editing provided by Barbara Galassi (Brighton, U.K)

Part of this research was supported by MIUR-2015 20158A9CBM Grant (C.B).

\section{References}

Aldridge, L.P., Finch, J, Gainsford, A.R., Tennant, W.C., Childs, C.W., 1987. Electricfield gradient in muscovites. American Mineralogist 72, 528-536.

Amisano-Canesi, A., Chiari, G., Ferraris, G., Ivaldi, G., Soboleva, S.V., 1994. Muscoviteand phengite-3T: crystal structure and conditions of formation. European Journal of Mineralogy 6, 489-496. 
Angel, R.J., Allan, D.R., Miletich, R., Finger, L.W., 1997. The use of quartz as an internal pressure standard in high pressure crystallography. Journal of Applied Crystallography 30, 461-466.

Brigatti, F., Guggenheim, S., 2002. Mica crystal chemistry and the influence of pressure, temperature, and solid solution on atomistic models. Reviews in Mineralogy and Geochemistry 46, 1-97.

Castelli, D., Rolfo, F., Compagnoni, R., Xu, S.T., 1998. Metamorphic veins with kyanite, zoisite and quartz in the Zhu-Jia-Chong eclogite, Dabie Shan, China. Island Arc 7(1-2), 159-173.

Chon C-M, Kim SA, Moon H-S, 2003. Crystal structure of biotite at high temperatures and of heat-treated biotite using neutron powder diffraction. Clays and Clay Minerals $51,519-528$.

Chon, C.-M., Lee, C.-K., Song, Y., Kim, S.-A., 2006. Structural changes and oxidation of ferroan phlogopite with increasing temperature: in situ neutron powder diffraction and Fourier transform infrared spectroscopy, Physics and Chemistry of Minerals 33(5), 289-299.

Comodi, P., Zanazzi, P.F., Weiss, Z., Rieder, M., Drábek, M., 1999. “Cs-ferri-tetraannite": high-pressure and high-temperature behavior of a potential nuclear waste disposal phase. American Mineralogist 84, 325-332.

Compagnoni, R., Engi, M., Regis, D., 2014. Val d'Aosta section of the Sesia Zone: multistage $\mathrm{H} P$ metamorphism and assembly of a rifted continental margin. $10^{\text {th }}$ Int. Eclogite Conf., Syn-Conference Excursion, 5 September 2013, GFT - Geological Field Trips, 6 (1.2), 1-44. ISSN: 2038-4947. (DOI 10.3301/GFT.2014.02) http://www.isprambiente.gov.it/it/pubblicazioni/periodici-tecnici/geological-field- 
trips/valle-daosta-section-of-the-sesia-zone.

Cong, B.-L., Wang, Q.C., Zhai, M., Zhang, R.Y., Zhao, Z.Y., Ye, K., 1994. Ultrahighpressure metamorphic rocks in the Dabishan-Sulu Region of China. Island Arc 3, $135-150$.

Curetti, N., Levy, D., Pavese, A., Ivaldi, G., 2006. Elastic properties and stability of coexisting 3T and 2M1 phengite polytypes. Physics and Chemistry of Minerals $32(10), 670-678$.

Curetti, N., Ferraris, G., Ivaldi, G., 2008. Correlation between crystallization pressure and structural parameters of phengites. American Mineralogist 93, 451-455.

Deng, L.-P., Liu, Y.-C., Gu, X.-F., Groppo, C., Rolfo, F., 2017. Partial melting of ultrahigh-pressure metamorphic rocks at convergent continental margins: Evidences, melt compositions and physical effects, Geoscience Frontiers. http://dx.doi.org/10.1016/j.gsf.2017.08.002

Desmons, J., O’Neill, J.R., 1978. Oxygen and hydrogen isotope compositions of eclogites and associated rocks from the eastern Sesia Zone (Western Alps, Italy). Contributions to Mineralogy and Petrology 67, 79-85.

Droop, G.T.R., Lombardo, B., Pognante, U., 1990. Formation and distribution of eclogite facies rocks in the Alps. In: D.A. Carswell, (Ed.) Eclogite Facies Rocks. Glasgow, Blackie, 225-259.

Ferrando, S., Frezzotti, M.L., Dallai, L., Compagnoni, R., 2005. Fluid-rock interaction in UHP phengite-kyanite-epidote eclogite from the Sulu Orogen, Eastern China. International Geology Review 47, 750-774.

Ferraris, G., Ivaldi, G., 2002. Micas: crystal chemistry and metamorphic petrology. Reviews in Mineralogy and Geochemistry 46, 117-153.

Ferraris, G., Ivaldi, G., Nespolo, M., Takeda, H., 1995. On the stability of dioctahedral 
micas. Terra Abstract (suppl. N.1 Terra Nova) 7, 289.

Ferraris, C., Chopin, C., Wessicken, R., 2000. Nano- to micro-scale decompression products in ultrahigh-pressure phengite: HRTEM and AEM study, and some petrological implications. American Mineralogist 85, 1195-1201.

Ferraris, C., Grobety, B., Wessicken, R., 2001. Phlogopite exsolution within muscovite: a first evidence for a higher-temperature re-equilibration, studied by HRTEM and AEM techniques. European Journal of Mineralogy 13, 15-26.

Ferrow, E.A., London, D., Goodman, K.S., Veblen, D.R., 1990. Sheet silicates of the Lawler Peak granite, Arizona: chemistry, structural variations, and exsolution. Contributions to Mineralogy and Petrology 105, 491-501.

Finch, J., Gainsford, A.R., Tennant, W.C., 1982. Polarized optical absorption and ${ }^{57} \mathrm{Fe}$ Mössbauer study of pegmatitic muscovite. American Mineralogist 67, 59-68.

Frank, W., Hock, V., Miller, C., 1986. Metamorphic and tectonic history of the Central Tauern Window. In: H.W. Flugel, P. Faupl (Eds.), Geodynamics of the Eastern Alps, Deuticke, Vienna, 34-54.

Frezzotti, M.L., Ferrando, S., Dallai, L., Compagnoni, R., 2007. Intermediate alkalialumino-silicate aqueous solutions released by deeply-subducted continental crust: fluid evolution in UHP OH-rich topaz-kyanite-quartzites from Donghai County (Sulu, China). Journal of Petrology 48, 1219-1241.

Gatta, G.D., Rotiroti, N., Pavese, A., Lotti, P., Curetti, N., 2009. Structural evolution of a 3T phengite mica up to $10 \mathrm{GPa}$ : an in-situ single-crystal X-ray diffraction study. Zeitschrift für Kristallographie 224, 302-310.

Gatta, G.D., Merlini, M., Rotiroti, N., Curetti, N., Pavese, A., 2011. On the crystal chemistry and elastic behavior of a phlogopite 3T. Physics and Chemistry of 
Minerals 38, 655-664.

Gemmi, M., Merlini, M., Pavese, A., Curetti, N., 2008. Thermal expansion and dehydroxylation of phengite micas. Physics and Chemistry of Minerals 35(7), 367379.

Goodman, B.A., 1976. The Mössbauer spectrum of a ferrian muscovite and its implications in the assignment of sites in dioctahedral micas. Mineralogical Magazine 40, 513517.

Gresens, R.L., Stensrud, H.L., 1971. Chemical, optical, and X-ray analysis of an unusual muscovite-biotite intergrowth. Lithos 4, 63-69.

Hazen, R.M., Finger, L.W., 1978. The crystal structures and compressibilities of layer minerals at high pressure. II Phlogopite and Chlorite. American Mineralogist 63, 293-296.

Hermann, J., Green, D.H., 2001. Experimental constraints on high pressure melting in subducted crust. Earth and Planetary Science Letters 188, 149-168.

Hermann, J., Rubatto, D., 2009. Accessory phase control on the trace element signature of sediment melts in subduction zones. Chemical Geology 265, 512-526.

Hirajima, T., Nakamura, D., 2003. The Dabie Shan-Sulu orogeny. In: D.A., Carswell and R., Compagnoni (Eds.), Ultrahigh-pressure metamorphism. E.M.U. Notes in Mineralogy 5, 105-144. Eötvös University Press, Budapest.

Holland, T.J.B., Powell, R., 1998. An internally consistent thermodynamic data set for phases of petrological interest. Journal of Metamorphic Geology 16, 309-343.

Ivaldi, G., Ferraris, G., Curetti, N., Compagnoni, R., 2001. Coexisting 3T and 2M1 polytypes of phengite from Cima Pal (Val Savenca, western Alps): Chemical and polytypic zoning and structural characterisation. European Journal of Mineralogy 
13, 1025-1034.

Lester, J.G., 1946. Inclusions in muscovite from Mitchell Creek Mine, Upson Country, Georgia. American Mineralogist 31, 77-81.

Li X.-P., Li Y.-L., Shu G.-M., 2005. Breakdown of lawsonite subsequent to peak UHP metamorphism in the Dabie terrane and its implication for fluid activity. Chinese Science Bulletin 50(13), 1366-1372.

Liu, Y.-C., Deng, L., Gu, X., Groppo, C., Rolfo, F., 2015. Application of Ti-in-zircon and $\mathrm{Zr}$-in-rutile thermometers to constrain high-temperature metamorphism in eclogites from the Dabie orogen, central China. Gondwana Research 27, 410-423.

Massonne, H.-J., Szpurka, Z., 1997. Thermodynamic properties of white micas on the basis of high-pressure experiments in the systems $\mathrm{K}_{2} \mathrm{O}-\mathrm{MgO}-\mathrm{Al}_{2} \mathrm{O}_{3}-\mathrm{SiO}_{2}-\mathrm{H}_{2} \mathrm{O}$ and $\mathrm{K}_{2} \mathrm{O}-$ $\mathrm{FeO}-\mathrm{Al}_{2} \mathrm{O}_{3}-\mathrm{SiO}_{2}-\mathrm{H}_{2} \mathrm{O}$. Lithos 41, 229-250.

Mattinson C.G., Zhang R-Y., Tsujimori T., Liou J.G., 2004. Epidote-rich talc-kyanitephengite eclogites, Sulu terrane, eastern China: P-T-fO2 estimates and the significance of the epidote-talc assemblage in eclogite. American Mineralogist 89(11-12), 1772-1783.

Merli, M., Pavese, A., Curetti, N., 2009. Maximum entropy method: an unconventional approach to explore observables related to the electron density in phengites. Physics and Chemistry of Minerals 36, 19-28.

Merli, M., Bonadiman, C., Diella, V., Sciascia, L., Pavese, A., 2017. Fe-periclase reactivity at Earth's lower mantle conditions: Ab-initio geochemical modelling. Geochimica et Cosmochimica Acta 214, 14-29.

Monier, G., Robert, J.L., 1986a. Muscovite solid solutions in the system $\mathrm{K}_{2} \mathrm{O}-\mathrm{MgO}-\mathrm{FeO}-$ $\mathrm{Al}_{2} \mathrm{O}_{3}-\mathrm{SiO}_{2}-\mathrm{H}_{2} \mathrm{O}$ : an experimental study at 2 kbar $\mathrm{P}_{\mathrm{H} 2 \mathrm{O}}$ and comparison with natural 
Li-free white micas. Mineralogical Magazine 50, 257-266.

Monier, G., Robert, J.L., 1986b. Evolution of the miscibility gap between muscovite and biotite solid solutions with increasing lithium content: an experimental study in the system $\mathrm{K}_{2} \mathrm{O}-\mathrm{Li}_{2} \mathrm{O}-\mathrm{MgO}-\mathrm{FeO}-\mathrm{Al}_{2} \mathrm{O}_{3}-\mathrm{SiO}_{2}-\mathrm{H}_{2} \mathrm{O}-\mathrm{HF}$ at $600^{\circ} \mathrm{C}, 2$ kbar $\mathrm{P}_{\mathrm{H} 2 \mathrm{O}}$ : comparison with natural lithium micas. Mineralogical Magazine 50, 641-651.

Pavese, A., Diella, V., 2007. Uncertainties on elastic parameters and occupancy factors: how do they affect the accuracy of the calculated Gibbs energy of minerals at $(\mathrm{P}, \mathrm{T})$ conditions? The case of $3 \mathrm{~T}$ - versus $2 \mathrm{M}_{1}$ phengite. Physics and Chemistry of Minerals 34(9), 637-645.

Pavese, A., Diella, V. 2013. How stacking disorder can conceal the actual structure of micas: the case of phengites. DOI:10.1007/s00269-013-0568-6. Physics and Chemistry of Minerals 40, 375-386.

Pavese., A., Ferraris, G., Pischedda, V., Ibberson, R., 1997. Cation Site ordering in phengite 3T from Dora Maira massif (western Alps): a variable-temperature neutron powder diffraction study. European Journal of Mineralogy 9, 1183-1190.

Pavese, A., Ferraris, G., Pischedda, V., Mezouar, M., 1999. Synchrotron powder diffraction study of phengite 3T from Dora Maira massif: P-V-T equation of state and petrological consequences. Physics and Chemistry of Minerals 26, 460-467.

Pavese, A., Ferraris, G., Pischedda, V., Radaelli, P., 2000. Further study of cation ordering in phengite 3T by neutron powder diffraction. Mineralogical Magazine 64, 11-18. 
Pavese, A., Ferraris, G., Pischedda, V., Fauth, F., 2001. M1-site occupancy in 3T and $2 \mathrm{M}_{1}$ phengites by low temperature neutron powder diffraction: Reality or artefact? European Journal of Mineralogy 13, 1071-1078.

Pavese, A., Curetti, N., Ferraris, G., Ivaldi, G., Russo, U., Ibberson, R., 2003 a. Deprotonation and order-disorder reactions as a function of temperature in a phengite 3T (Cima Pal, western Alps) by neutron diffraction and Mössbauer spectroscopy. European Journal of Mineralogy 15, 357-363.

Pavese, A., Levy, D., Curetti, N., Diella, V., Sani, A., 2003b. Equation of state and compressibility of phlogopite by in-situ high pressure X-ray diffraction experiment. European Journal of Mineralogy 15, 455-463.

Pavese, A., Curetti, N., Diella, V., Levy, D., Dapiaggi, M., Russo, U., 2007. $P-V$ and $T-V$ Equations of State of natural biotite: an in-situ high pressure and high temperature powder diffraction study, combined with Mössbauer spectroscopy. American Mineralogist 92(7), 1158-1164.

Petricek, V., Dusek, M., Palatinus, L., 2014. Crystallographic Computing System JANA2006: General features. Zeitschrift für Kristallographie 229(5), 345-352.

Poli, S., Fumagalli P., 2003. Mineral assemblages in ultrahigh pressure metamorphism: A review of experimentally determined phase diagrams. In: D.A. Carswell and R. Compagnoni (Eds.) Ultrahigh-pressure metamorphism. E.M.U. Notes in Mineralogy 5, 307-340. Eötvös University Press, Budapest.

Rieder, M., Cavazzini, G., D’Yakonov, Yu.S., Frank-Kamenetskii, V.A., Gottardi, G., Guggenhein, S., Koval, P.V., Müller, G., Neiva, A.M.R., Radoslovich, E.W., Robert, J.L., Sassi F.P., Takeda, H., Weiss Z., Wones, D.R., 1998. Nomenclature of the micas. The Canadian Mineralogist 36, 905-912. 
617 Geological Society of America, 1991: Rock color chart with genuine Munsell ${ }^{\mathrm{R}}$ color chips. Boulder, Colo Ed.

619

620

621

622

623

624

625

626

627

628

629

630

631

632

633

634

635

Russell, R.L., Guggenheim, S., 1999. Crystal structures of near-end-member phlogopite at high temperatures and heat-treated Fe-rich phlogopite: The influence of the $\mathrm{O}, \mathrm{OH}$, F site. The Canadian Mineralogist 37, 711-720.

Sassi, F.P., Guidotti, C., Rieder, M., De Pieri, R., 1994. On the occurrence of metamorphic 2M1 phengites: some thoughts on polytypism and crystallization condition of $3 \mathrm{~T}$ phengites. European Journal of Mineralogy 6, 151-160.

Schingaro, E., Lacalamita, M., Scordari, F., Mesto, E., 2013. 3T-phlogopite from Kasenyi kamafugite (SW Uganda): EPMA, XPS, FTIR and SCXRD study. American Mineralogist 98, 709-717.

Schmidt, M.W., Poli, S., 1998. Experimentally based water budgets for dehydrating slabs and consequences for arc magma generation. Earth and Planetary Science Letters $163,361-379$.

Schmidt, M. W., Vielzeuf, D., Auzanneau, E., 2004. Melting and dissolution of subducting crust at high pressures: the key role of white mica. Earth and Planetary Science Letters 228, 65-84.

Shabani, A.A.T., Rancourt, D.G., Lalonde, A.E., 1998. Determination of cis and trans Fe2+ populations in $2 \mathrm{M}(1)$ muscovite by Mossbauer spectroscopy. Hyperfine Interactions, 117, 117-129.

Sheldrick, G.M., 1997. SHELXL-97, Program for the Refinement of Crystal Structure; University of Göttingen, Germany.

Smyth, J.R., Jacobsen, S.D., Swope, R.J., Angel, R.J., Arlt, T., Domanik, K., Holloway, J.R., 2000. Crystal structures and compressibilities of synthetic $2 \mathrm{M}_{1}$ and $3 \mathrm{~T}$ 

phengite micas. European Journal of Mineralogy 12(5), 955-963.

Takeda, H., Morosin, B., 1975. Comparison of observed and predicted structural parameters of mica at high temperature. Acta Crystallographica B31, 2444-2452.

Thomsen, T.B., Schmidt, M.W., 2008. The Biotite to Phengite Reaction and Micadominated Melting in Fluid+Carbonate-saturated Pelites at High Pressures. Journal of Petrology 49, 1889-1914.

Tutti, F., Dubrovinsky, LS., Nygren, M., 2000. High-temperature study and thermal expansion of phlogopite. Physics and Chemistry of Minerals 27(9), 599-603.

Ventruti, G., Levy, D., Pavese, A., Scordari, F., Suard, E., 2009. High-temperature treatment, hydrogen behaviour and cation partitioning of a Fe-Ti bearing volcanic phlogopite by in situ neutron powder diffraction and FTIR spectroscopy. European Journal of Mineralogy 21(2), 385-396.

Weiss, Z., Rieder, M., Smrcok, L., Petricek, V., Bailey, S.W., 1993. Refinement of the crystal structures of two "protolithionites". European Journal of Mineralogy 5, 493-502.

Wright, T.L., Doherty, P.C., 1970. A linear programming and least-squares computer method for solving petrologic mixing problems. Geological Society of America Bulletin 81, 1995-2008.

Xu, H.J., Ye, K., Zhang, J.F., 2012. Temperature of prograde metamorphism, decompressional partial melting and subsequent melt fractional crystallization in the Weihai migmatitic gneisses, Sulu UHP terrane: constraints from Ti-in-zircon thermometer. Journal of Earth Sciences 23, 813-827.

Zanazzi, P.F. and Pavese, A., 2002. Behavior of micas at high pressure and high temperature. Reviews in Mineralogy and Geochemistry 46, 98-116. 
Zhang, R. Y., Hirajima, T., Banno, S., Cong, B., Liou, J. G., 1995. Petrology of ultrahighpressure rocks from the southern Sulu region, eastern China. Journal of Metamorphic Geology 13, 659-675.

Zhang, R.Y., Yang, J.S., Wooden, J.L., Liou, J.G., Li, T.F., 2005. U-Pb SHRIMP geochronology of zircon in garnet peridotite from Sulu UHP terrane, China: implications for mantle metasomatism and subduction-zone UHP metamorphism. Earth and Planetary Science Letters 237, 729-743.

Zhang, Z.M., Xiao, Y.L., Liu, F., Liou, J.; Hoefs, J., 2005. Petrogenesis of UHP metamorphic rocks from Qinglongshan, Southern Sulu, East-Central China. Lithos $81,189-207$

Zheng, Y., Zhou, J.-B., Wu, Y.-B., Xie, Z., 2005. Low-grade metamorphic rocks in the Dabie-Sulu orogenic belt: a passive-margin accretionary wedge deformed during continent subduction. International Geology Review 47, 851-871. 
Figure 1. Simplified geologic sketch map of the Sulu orogen showing major tectonic units. YQWF, Yantai-Qingdao-Wulian fault White circles mark the location of labelled towns (from Mattinson et al., 2004 and Zhang et al., 2005, modified); The phengite+quartz metamorphic vein was excavated at Qinglongshan (evidenced in the map), in the Donghai County.

Figure 2. Optical micrograph (plane polarised light) of Fe-phlogopite quasi-exsolution (brown colour) developed in pyramidal form (its thickness increases toward the centre), with several evident growth stages.

Figure 3. Optical micrographs of mica quasi-exsolutions and quartz crystals in trigonal phengite observed under plane polarised (a) light and crossed polarised (b) lights, respectively. The quasi-exsolution is apparent in (a) (darker portions) while the micaquartz reaction is amplified in (b) (white portions).

Figure 4. Mössbauer spectrum collected on Phe-3T sample. The peaks are fitted with three doublets and they indicate that $57(1) \%$ of the total Fe is trivalent, $43(1) \%$ bivalent (parameters in Table S1).

Figure 5. Changes of chemical composition from Phe-3T to Phl-3T; (a) schematic representation of the analysed sample and location of the analysis points. (b) The histogram reports the variation by weight $\%$ of the principal oxides; approaching the quasiexsolved phases, $\mathrm{Si}$ and $\mathrm{Al}$ decrease, while $\mathrm{Fe}$ and $\mathrm{Mg}$ increase. 
Figure 6. Pressure-temperature loci of equilibrium for the phengite-phlogopite-quartz reaction (eq. 2). The cases of $\Delta G\left(P_{0}, T_{0}\right)+\mathrm{I}_{T-T_{0}}$ equal to 10 and $15 \mathrm{~kJ} / \mathrm{mol}$ are shown.

The blue line represents the Sulu UHP-HP metamorphic $P-T$ evolution stages from the prograde metamorphic peak at $P \sim 3.5 \mathrm{GPa}$ and $T \sim 780{ }^{\circ} \mathrm{C}$ (large blue square) to the late stage of exhumation $P \sim 0.3 \mathrm{GPa}$ and $T \sim 400{ }^{\circ} \mathrm{C}$ (small blue square). The intersection of the calculated equilibrium $P-T$ locus of phengite-phlogopite-quartz reaction with the metamorphic path (from Frezzotti et al., 2007) is marked by the blue box. 
1 Phengite megacryst quasi-exsolving phlogopite, from Sulu Ultra-high Pressure

2 Metamorphic Terrane, Qinglongshan, Donghai County (eastern China): new data for

$5 \quad$ Nadia Curetti ${ }^{\mathrm{a}}$, Costanza Bonadiman ${ }^{\mathrm{b}}$, Roberto Compagnoni ${ }^{\mathrm{a},}$ Luca Nodari $^{\mathrm{c}}$, Ingrid

6 Corazzari $^{\mathrm{d}, \mathrm{e}}$, Alessandro Pavese ${ }^{\mathrm{a}}$

$8 \quad{ }^{a}$ Department of Earth Sciences, University of Turin, 10125 Turin, Italy

$9 \quad{ }^{\mathrm{b}}$ Department of Physics and Earth Sciences, University of Ferrara, 44122 Ferrara, Italy

$10{ }^{\mathrm{c}}$ Institute of Condensed Matter Chemistry and Technology for the Energy- CNR - Padua, Italy

$11{ }^{\mathrm{d}}$ Department of Chemistry, University of Turin, 10125 Turin, Italy

12 e "G. Scansetti" Interdepartmental Center for Studies on Asbestos and Other Toxic Particulates, Turin, Italy.

key-words: phengite and phlogopite micas, exolution reactions, Sulu UHP metamorphic terrane, alkali-alumino-silicate high pressure fluids.

corresponding author: Costanza Bonadiman (bdc @unife.it)

In memory of Prof. Xu Shutong 
Abstract

A large crystal of trigonal phengite (Phe-3T; $\left.\left.\mathrm{K}_{0.96} \mathrm{Na}_{0.02} \mathrm{Ba}_{0.01}\right)\left(\mathrm{Al}_{1.35} \mathrm{Mg}_{0.40} \mathrm{Fe}^{2+}{ }_{0.11} \mathrm{Fe}^{3+}{ }_{0.13} \mathrm{Ti}_{0.02}\right)_{\Sigma=2.02}\left[\mathrm{Si}_{3.44} \mathrm{Al}_{0.56}\right] \mathrm{O}_{10}(\mathrm{OH})_{2}\right), \quad$ sampled from a phengite+quartz metamorphic vein in the eclogites-bearing rocks of Sulu UHP metamorphic terrane, exhibits unusual thin lamellae of ferrian-aluminian $\begin{array}{lll}\text { trigonal/monoclinic } & \text { phlogopite } & \text { polytypes }\end{array}$ $\left(\mathrm{K}_{0.78} \mathrm{Na}_{0.01}\right)\left(\mathrm{Mg}_{1.48} \mathrm{Fe}^{2+}{ }_{0.39} \mathrm{Fe}^{3+}{ }_{0.45} \mathrm{Al}_{0.30} \mathrm{Ti}_{0.06}\right)_{\Sigma=2.68}\left[\mathrm{Si}_{2.98} \mathrm{Al}_{1.02}\right] \mathrm{O}_{10}\left((\mathrm{OH})_{1.77} \mathrm{~F}_{0.23}\right) ; \quad$ Phl-1M: $\left.\left(\mathrm{K}_{0.85} \mathrm{Ca}_{0.01}\right)\left(\mathrm{Mg}_{1.43} \mathrm{Fe}^{2+}{ }_{0.45} \mathrm{Fe}^{3+}{ }_{0.54} \mathrm{Al}_{0.21} \mathrm{Ti}_{0.06}\right)_{\Sigma=2.69}\left[\mathrm{Si}_{2.88} \mathrm{Al}_{1.12}\right] \mathrm{O}_{10}\left((\mathrm{OH})_{1.99} \mathrm{~F}_{0.01}\right)\right) . \quad$ This assemblage is rarely observed in UHP eclogite-bearing rocks, and has never been reported before in the Sulu UHP metamorphic terrane. A detailed crystal-chemical characterisation of Phe-3T, Phl-3T and Phl-1M allowed the development of a thermodynamic model that estimates the $P-T$ conditions of formation of such an assemblage and helps to understand the relationship between mica polytypes and a quartz dominated (silica oversaturated) system, which characterized the Sulu vein. Phe-3T varies in composition upon approaching Phl-3T/1M, showing a decrease of $\mathrm{Si}$ and $\mathrm{Al}$ and an increase of $\mathrm{Fe}$ and $\mathrm{Mg}$ contents. Observed phlogopites cannot be ascribed to bare exsolving processes, and require the involvement of a non-isochemical reaction, dominated by exsolution (quasi-exsolution process) in combination with a contribution from an "external chemical supplier" (most probably provided by circulating fluids). Mass balance calculations between the mineralogical assemblage of Sulu vein and the solute components of alkali-aluminosilicate high pressure fluids demonstrate that a silicic-type major element composition accounts for a phengite-quartz based rock. The occurrence of phlogopite micas can be explained as an effect of disproportion in combination with supply components, i.e. $\mathrm{Mg}, \mathrm{Al}$ and $\mathrm{K}$, from alkali-alumino-silicate high pressure fluids. 
On the basis of energy modelling of the reaction process from phengite to phlogopite in presence of quartz and a matter exchanger, we determined that such a transformation is weakly dependent on $T$ over the $500-930^{\circ} \mathrm{C}$ thermal range. The intersection of the calculated $P-T$ assemblage equilibrium curve with the country rock $P-T$ metamorphic path occurs at $P \sim 2.4 \pm 0.2 \mathrm{GPa}$ and $T \sim 700^{\circ} \mathrm{C}$, thus reflecting an early stage of exhumation, close to the metamorphic peak of the Sulu UHP terrane.

\section{Introduction}

During prograde metamorphism, veins promoted by the availability of the fluid released by the dehydration reactions accompanying temperature (and pressure) increase are ubiquitous (Cong et al. 1994; Zheng et al., 2005). In case of decarbonation reactions, $\mathrm{CO}_{2}$ also occurs in the fluid phase and carbonate minerals may form in place of or together with silicates. The vein mineral assemblage, which reflects the occurring $P-T-X$ conditions at the time of its formation, is useful to infer the metamorphic path experienced by a rock during the whole tectonic evolution. Usually, a close relationship exists between the country rock and the mineralogical composition of the metamorphic vein: e.g., in lowgrade metapelites, most metamorphic veins consist of quartz and/or low-temperature minerals such as Fe-rich chlorite and epidote (Hermann and Rubatto, 2009).

Conversely to a widespread opinion that eclogites form at dry conditions or at very low water activity, metamorphic veins involving fluids are not unusual in the HP (high pressure) and UHP (ultra-high pressure) eclogite-facies (Poli and Fumagalli, 2003). For example, in eclogites quartz-rutile veins are ubiquitous, and they were used to estimate the metamorphic temperatures by means of the oxygen isotopes partitioning (e.g., Desmons and O’Neill, 1978). 
Good examples of such HP veins in subducted continental crust are found in the "Eclogitic Micaschist Complex" of the Sesia Zone, Western Alps, where quartz veins may include rutile crystals, more than $20 \mathrm{~cm}$ long (Compagnoni et al., 2014 and references therein). In the same unit, a metamorphic vein was found, 1-2 m thick and more than $80 \mathrm{~m}$ long, mainly consisting of phengite and minor quartz: the phengite flakes, which are up to $30 \mathrm{~cm}$ wide, show a unique oscillatory zoning and the coexistence of $3 T$ and $2 M_{1}$ polytypes, and no evidence of phlogopite polytypes (Ivaldi et al., 2001).

In the HP/UHP eclogites of the Dabie-Sulu orogenic belt, in addition to the ubiquitous quartz-rutile veins, quartz+zoisite+kyanite veins were found in the Zhu-Jia-Chong eclogite body, where the vein minerals may also attain a pegmatoid size (Castelli et al., 1998). It was proposed that such veins were formed in a closed system during the breakdown of lawsonite which resulted in a kyanite +zoisite +hydrous fluid, either before peak metamorphic conditions (Castelli et al., 1998) or during exhumation (Li et al., 2005).

These metamorphic veins are quite different from veins formed by partial melting during exhumation, which are characterised by a mineral assemblage that reflects the minimum melting granite, i.e. the ubiquitous presence of feldspars and mineral grain-size of the order of millimetres (Deng et al., 2017 and references therein).

The phengite specimen under investigation was sampled from a phengite+quartz metamorphic vein, excavated at Qinglongshan, very close to the G30 Lianhuo Expressway, crossing the Donghai County (eastern China). The phengite was collected in a small dump derived from a vertical shaft, excavated in the eclogites-bearing rocks of Sulu UHP metamorphic terrane to mine pure quartz (Fig. 1).

The peak conditions of the UHP metamorphism of the Qinglongshan rocks were estimated at $T \sim 700-800^{\circ} \mathrm{C}$ and $P>2.8 \mathrm{GPa}$ (Hirajima and Nakamura, 2003; Liu et al., 2015; Xu et al., 
2012; Zhang et al., 1995) and several $P$-T paths have been suggested (e.g., Ferrando et al., 2005; Frezzotti et al., 2007).

The phengite sample consists of a single undeformed platy crystal, about $520 \mathrm{~cm}^{3}$ in volume, with a dusky yellowish green colour (Rock Colour Chart, 1991), and it shows the unusual thin lamellae of Fe-phlogopite.

The coexistence of phengite and phlogopite is rarely observed in UHP eclogite-bearing rocks (e.g., Eastern Alps; Eclogite Zone, Tauern, Austria; Frank et al.,1986) and, to the authors' knowledge, has never been reported from Sulu UHP terrane.

The condition and nature of the reactions that lead to the equilibrium of phengite with phlogopite (Zanazzi and Pavese, 2002) upon decreasing pressure are still poorly defined. Melting experiments, conducted on the synthetic $\mathrm{K}_{2} \mathrm{O}-\mathrm{MgO}-\mathrm{Al}_{2} \mathrm{O}_{3}-\mathrm{SiO}_{2}-\mathrm{H}_{2} \mathrm{O}$ (KMASH) system (Massonne and Szpurka, 1997; Thomsen and Schmidt, 2008) and on natural carbonate-bearing eclogites (Droop et al., 1990; Zhang et al., 1995), suggest that a silicate melt at $P>2 \mathrm{kbar}$ and $600^{\circ}<T<700^{\circ} \mathrm{C}$ produces volatile-rich phases, among which phengite plays a relevant role as potassic mineral (Hermann and Green, 2001; Massonne and Szpurka, 1997; Schmidt and Poli, 1998;; Schmidt et al., 2004).

In view of this, the finding in a quartz+mica assemblage of a large crystal of phengite together with seemingly exsolved phlogopite motivated the present investigation. Note that, an exsolving process in a closed system alone cannot account for the coexistence of phengite and phlogopite, and complex metasomatic reactions involving fluids are also to be assumed. The aim of this work is to provide a thermodynamic model that estimates the $P-T$ of formation, starting from a detailed crystal-chemical characterisation of the involved micas.

Phengites $(P h e)$ are dioctahedral micas (ideal composition: $\mathrm{KAl}_{2-\mathrm{x}}\left(\mathrm{Fe}, \mathrm{Mg}_{\mathrm{x}}\left[\mathrm{Si}_{3+\mathrm{x}} \mathrm{Al}_{1-}\right.\right.$ 
$115{ }_{\mathrm{x}} \mathrm{JO}_{10}(\mathrm{OH})_{2}$ ) that usually occur in nature as $2 M_{1}$ (more abundant) and $3 T$ polytypes (S.G. $C 2 / c$ and $P 3_{1} 12$, respectively). Several $3 T$ structures were refined and reported in literature (Amisano-Canesi at al., 1994; Ivaldi et al., 200; Pavese et al., 1997, 1999, 2000, 2003a; Smyth et al., 2000; Weiss et al., 1993), although special attention must be paid to the reliability of the occupancy factors (Pavese and Diella, 2013). Because of its occurrence in high-pressure metamorphic rocks, the $3 T$ polytype is thought to be more suitable for high $P$ conditions than $2 M_{1}$. The $3 T$ polytype presents two independent occupied octahedral-sites (Ferraris et al., 1995; Ferraris and Ivaldi, 2002) while the $2 M_{1}$ only shows one. The $3 T$ to $2 M_{1}$ transition is supposed to take place upon decreasing the $P / T$ ratio (Ivaldi et al., 2001; Sassi et al., 1994). The occurrence of one polytype instead of the other is useful in constraining the pressure-temperature conditions of formation.

In the metamorphic dioctahedral micas, the ${ }^{\mathrm{IV}} \mathrm{Si}$ content increases with increasing crystallisation pressure. Single crystals of quartz platelets, 100-700 Å thick, were observed, along with talc, in a phengite coming from the UHP Brossasco-Isasca Unit of southern Dora-Maira Massif, Western Italian Alps (Ferraris et al., 2000). Their occurrence was related to an intra-crystalline re-organisation during decompression of the original phengites.

Phlogopites $(P h l)$ are trioctahedral micas (ideal composition $\mathrm{KMg}_{3}\left[\mathrm{Al} \mathrm{Si}_{3}\right] \mathrm{O}_{10}(\mathrm{OH})_{2}$ ) that usually crystallise as $1 M$ (S.G. $C 2 / m$ ) and rarely as $3 T$ (S.G. $\left.P 3_{1} 12\right)$ polytypes. Only two phlogopites $3 T$ were refined and reported in literature: the first one comes from Traversella - Western Alps (Gatta et al., 2011) and the second from Kasenyi - Uganda (Schingaro et al., 2013).

A miscibility gap between dioctahedral and trioctahedral micas is known. Lester (1946) and Gresen et al. (1971) described exsolutions in micas coming from Mitchell Creek 
139 (Georgia, USA). The quoted authors observed unusual and pyramidal intergrowths of biotite in muscovite. Two instances of transmission electron microscopy investigations on trioctahedral exsolutions in magmatic muscovite $2 M_{1}$ were reported: very small exsolutions ( 10nm scale) in muscovite from Lawler Peak granite -Arizona (Ferrow et al., $1990)$ and ferro-aluminian phlogopitic lamellae ( 1 mm scale) in muscovite from pegmatite outcropping near Gorduno -Switzerland (Ferraris et al., 2001). Experimental studies in the system $\mathrm{K}_{2} \mathrm{O}-\mathrm{M}^{2+}-\mathrm{Al}_{2} \mathrm{O}_{3}-\mathrm{SiO}_{2}-\mathrm{H}_{2} \mathrm{O} \pm(\mathrm{HF})$ with $\mathrm{M}^{2+}=\mathrm{Mg}^{2+}$ or $\mathrm{Fe}^{2+}$ at $P \sim 2 \mathrm{kbar}$ and variable $T\left(200-700^{\circ} \mathrm{C}\right)$ showed a relevant dependence of the solid solution stability on temperature (Monier and Robert, 1986a, 1986b).

Understanding the principles underlying the coexistence of the observed phengite and phlogopite in a quartz dominated (silica oversaturated) mineral assemblage of the Sulu vein, will shed light on the "peculiar" $P-T-X$ conditions and evolution of the process involved in their formation.

\section{Materials and Methods}

\subsection{Sample Description}

The original specimen is a large, flat, regular flake (about $20 \mathrm{~cm} \times 15 \mathrm{~cm} \times 2 \mathrm{~cm}$ ) of a seemingly hosting phengite mica, characterised by a homogeneous deep green colour. Optical observations and single crystal X-ray rotation photos were performed on several samples extracted from different regions of the phengite mica. They confirmed an overall homogeneous trigonal symmetry of the phengite mica (Fig. 2).

In some areas of the sample, especially near the margins of the flake, associations of quartz and brown micas were observed (Fig. 3). Their nucleation and growth are clearly 
successive to the hosting phengite crystallisation, because of the preserved iso-orientation of the (001) plane in both hosted- and hosting-micas. This suggests the occurrence of exsolving processes, with the contribution from an "external chemical supplier" (most probably ascribable to fluid circulation). Therefore, the term "quasi-exsolution" is used hereafter to address a non-isochemical exsolution process. Such quasi-exsolved micas have sub-millimetre extension and micrometre thickness; their shape can be euhedral and pyramidal (Lester, 1946. Fig. 2), or irregular (Fig. 3). Several quasi-exsolved mica samples were extracted and tested by single crystal X-ray rotation photos. Most of the specimens are trigonal, and only a few present monoclinic symmetry.

\subsection{Analytical methods}

A fragment of the original mica-matrix sample was grounded to carry out preliminary $\mathrm{X}$ ray powder diffraction characterisations. The measurements were performed by a HuberGuinier 670 camera, $\mathrm{CuK} \alpha$ radiation, scan range $2^{\circ}<2 \theta<70^{\circ}$ and the diffraction patterns were processed by the GSAS Software Package.

The combination of X-ray powder diffraction, optical observations and chemical composition from micro-analyses, revealed the simultaneous occurrence of a major phengite (hereafter Phe-3T) and two minor phlogopite polytypes (Phl-3T and Phl-1M, for trigonal and monoclinic quasi-exsolved phlogopites, respectively). Single crystal specimens were separated for X-ray diffraction, which was performed at room temperature using MoK $\alpha$ radiation by both a Siemens P4 diffractometer, equipped with a point detector (University of Turin), and a Gemini R Ultra X-ray diffractometer, equipped with a Ruby CCD detector (CrisDi Interdepartmental Center for Crystallography, University of Turin). The former was used to measure lattice parameters of the samples under investigation; the latter to record diffraction intensities. Because of the limited crystal thickness, the quasi- 
exsolved crystals provided a comparatively small number of $h k l$-reflections. Structure refinements have been performed using both SHELXL-97 package (Sheldrick, 1997) and Jana2006 software (Petricek et al., 2014). Phl-3T data allowed a structure refinement using isotropic atomic displacement parameters, only. Single crystal X-ray diffraction experimental setup, overall refinement conditions and lattice parameters of each phase are reported in Table S1.

Four fragments from different areas of the original hosting-phengite flake were embedded in epoxy resin and analysed to determine their for chemical composition. Major element compositions were obtained by an ARL-SEMQ electron microprobe analyser (EMPA) equipped with wavelength- and energy-dispersive spectrometers (University of Modena and Reggio Emilia). The following operating conditions were set: $15 \mathrm{kV}$ and $20 \mathrm{nA}$ beam current. Quartz $(\mathrm{Si})$, corundum $(\mathrm{Al})$, periclase $(\mathrm{Mg})$, magnetite $(\mathrm{Fe})$, rhodonite $(\mathrm{Mn})$, grossular $(\mathrm{Ca})$, rutile $(\mathrm{Ti})$, chromium oxide $(\mathrm{Cr})$, vanadinite $(\mathrm{V})$, albite $(\mathrm{Na})$, apatite $(\mathrm{P})$ have been used as standards for the elements in parentheses.

Mössbauer spectroscopic analyses were performed on the Phe-3T sample in order to quantify $\mathrm{Fe}^{2+}$ and $\mathrm{Fe}^{3+}$. The spectrum was collected at room temperature on about $80 \mathrm{mg}$ of powdered sample (Fig. 4), by a conventional constant acceleration spectrometer, using a rhodium matrix ${ }^{57}$ Co source, nominal strength $1850 \mathrm{mBq}$ (University of Padua). To reduce the crystal iso-orientation, a "magic angle" setting was used $\left(54^{\circ}\right.$ between the incident beam and the sample plain). The hyperfine parameters isomer shift $(\delta)$, quadrupole splitting $(\Delta)$, full linewidth at half maximum $(\Gamma)$, were expressed in mms -1 while the relative area (A) in \%. The parameters were obtained by means of standard least-squares minimiaation techniques. The spectra were fitted to Lorentzian line shapes with the minimum number of doublets. $\delta$ is quoted to $\alpha$-Fe, using a 4-lines calibration. 
The water content was assessed by means of thermogravimetric analyses (TGA). TG

213 analyses were carried out under dynamic nitrogen atmosphere $\left(35 \mathrm{~mL} \mathrm{~min}^{-1}\right)$ by a Pyris 1

214 ultra-micro-balance - Perkin Elmer. The sample was heated in the temperature range 30-

$2151000{ }^{\circ} \mathrm{C}$ (heating rate $20{ }^{\circ} \mathrm{C} \min ^{-1}$ ) and an overall weight loss of $4.5 \%$ was observed. A

216 first process, observed between 30 and $180{ }^{\circ} \mathrm{C}$, was responsible for a weight loss of $0.5 \%$

217 and was attributed to the desorption of physisorbed water. From $180^{\circ} \mathrm{C}$ the sample 218 continuously lost weight up to $980{ }^{\circ} \mathrm{C}$ due to a not well defined process which was 219 responsible for a weight loss of $4 \%$ and was reasonably attributed to the evolution of 220 structural water.

\section{Results}

Phe-3T and quasi-exsolved Phl-phases major element compositions are reported in Table

1, whereas the doublets best fit parameters of Mössbauer patterns are listed in Table S2.

On the basis of EMPA and Mössbauer analyses, the chemical formula unit of Phe-3T (calculated according to 22 negative charges) is:

$\left(\mathrm{K}_{0.96} \mathrm{Na}_{0.02} \mathrm{Ba}_{0.01}\right)\left(\mathrm{Al}_{1.35} \mathrm{Mg}_{0.40} \mathrm{Fe}^{2+}{ }_{0.11} \mathrm{Fe}^{3+}{ }_{0.13} \mathrm{Ti}_{0.02}\right)_{\Sigma=2.02}\left[\mathrm{Si}_{3.44} \mathrm{Al}_{0.56}\right] \mathrm{O}_{10}(\mathrm{OH})_{2}$.

Quantitative chemical analyses performed on the Phl-3T specimens provided the following chemical formula unit:

$\left(\mathrm{K}_{0.78} \mathrm{Na}_{0.01}\right)\left(\mathrm{Mg}_{1.48} \mathrm{Fe}^{2+}{ }_{0.39} \mathrm{Fe}^{3+}{ }_{0.45} \mathrm{Al}_{0.30} \mathrm{Ti}_{0.06}\right)_{\Sigma=2.68}\left[\mathrm{Si}_{2.98} \mathrm{Al}_{1.02}\right] \mathrm{O}_{10}\left((\mathrm{OH})_{1.77} \mathrm{~F}_{0.23}\right)$.

232 Comparing the two compositions, $P h l-3 T$ is consistently richer in Fe and $\mathrm{Mg}$ than Phe-3T,

233 but the ${ }^{\mathrm{VI}} \mathrm{Mg} /{ }^{\mathrm{VI}} \mathrm{Fe}$ ratio in the two phases is similar $\left[\left({ }^{\mathrm{VI}} \mathrm{Mg} /{ }^{\mathrm{VI}} \mathrm{Fe}\right){ }_{\text {Phe-3T }}=1.70\right.$, $\left.234 \quad\left({ }^{\mathrm{VI}} \mathrm{Mg} /{ }^{\mathrm{VI}} \mathrm{Fe}\right)_{P h l-3 T}=1.63\right]$.

235 The analyses on the quasi-exsolved monoclinic polytype, Phl-1M, provided a chemical 
composition very close to the trigonal polytype's:

$\left(\mathrm{K}_{0.85} \mathrm{Ca}_{0.01}\right)\left(\mathrm{Mg}_{1.43} \mathrm{Fe}^{2+}{ }_{0.45} \mathrm{Fe}^{3+}{ }_{0.54} \mathrm{Al}_{0.21} \mathrm{Ti}_{0.06}\right)_{\Sigma=2.69}\left[\mathrm{Si}_{2.88} \mathrm{Al}_{1.12}\right] \mathrm{O}_{10}\left((\mathrm{OH})_{1.99} \mathrm{~F}_{0.01}\right)$.

Changes of composition from Phe-3T to its phlogopite quasi-exsolved products were measured along radial directions departing from the separation edge (Fig. 5). A shell with variable width $(\sim 300-500 \mu \mathrm{m})$ and zoned composition was found: approaching the quasiexsolved phases, $\mathrm{Si}$ and $\mathrm{Al}$ decrease, while $\mathrm{Fe}$ and $\mathrm{Mg}$ increase (Table 1; Fig.5). Midway along the transition region from phengite to phlogopite, the following approximated composition occurs:

$\left(\mathrm{K}_{0.89} \mathrm{Na}_{0.02}\right)\left(\mathrm{Al}_{1.24} \mathrm{Fe}_{0.52} \mathrm{Mg}_{0.54} \mathrm{Ti}_{0.02}\right)_{\Sigma=2.32}\left[\mathrm{Si}_{3.16} \mathrm{Al}_{0.84}\right] \mathrm{O}_{10}(\mathrm{OH})_{2}$.

The compositions of Phl-1M and Phl-3T correspond in micas' nomenclature (Rieder et al., 1998) to "ferrian aluminian phlogopite"; abbreviated to "phlogopite" in the rest of the study.

\subsection{Phe-3T and Phl-polytypes}

\subsubsection{Phe-3T}

The average distances $\langle\mathrm{T} 1-\mathrm{O}\rangle$ and $\langle\mathrm{T} 2-\mathrm{O}\rangle$ are equal (1.631(1) $\AA$; Tables S3 and S4) and in agreement with literature values. The ditrigonal rotation (Table S5) of the tetrahedral sheet $\left(\sim 48^{\circ}\right)$ is in keeping with a HP regime (Curetti et al., 2008).

The average distances $\langle$ M2-O $\rangle$ and $\langle$ M3-O $\rangle$ are meaningfully different $(1.958(1) \AA$ and 1.972(1) ̊̊, respectively) and indicate a partial octahedral ordering of large cations in M3, although the refined number of electrons (14.3(2) $e$ and 14.7(2) $e$ in M2 and M3, respectively; Table S3) cannot confirm this inference from bond-lengths.

Mössbauer spectroscopy suggests partial octahedral ordering of iron: (i) $\mathrm{Fe}^{3+}$ absorption is 
modelled by only one doublet, which suggest that the trivalent iron is completely ordered in one octahedron (0.13 $\mathrm{Fe}^{3+}$ a.p.f.u.); (ii) $\mathrm{Fe}^{2+}$ absorption is fitted by two doublets, each corresponding to one site (0.05 and $0.06 \mathrm{Fe}^{2+}$ a.p.f.u.). Several Mössbauer analyses on dioctahedral micas $2 M_{1}$ were reported in literature (Aldrige et al., 1987; Finch et al., 1982; Goodman, 1976; Shabani et al., 1998). The patterns usually show two different doublets for $\mathrm{Fe}^{2+}$, even if they are expected to have only one occupied symmetry independent octahedral site. To explain the unexpected second doublet (very weak and corresponding to 0.03-0.04 $\mathrm{Fe}^{2+}$ a.p.f.u., at most) the quoted authors assumed a partial occupancy of the M1trans site. The $3 T$ polytype has two independent octahedral sites (M2 and M3) and the two $\mathrm{Fe}^{2+}$ doublets can be assigned without resorting to the M1 empty site (Merli et al., 2009; Pavese et al., 2000; Pavese et al., 2001;). In fact, partial and very low M1 occupancy is suggested by both chemical analyses (octahedral cations sum $=2.02$ a.p.f.u.) and structural refinement (0.86 $e$ in the Fourier difference, 0.3(1) $e$ refined), though the electron content corresponding to each Mössbauer doublet is too high in comparison with the M1 refined occupancy (0.05 a.p.f.u. corresponding to about $1.3 e$ ). Mössbauer spectroscopy is not able to univocally associate iron doublets to specific sites, however its combination with structure refinements allows one to infer a partially ordered distribution of $\mathrm{Fe}, \mathrm{Al}$ and $\mathrm{Mg}$. The M1 octahedral site is almost completely empty. The $\mathrm{H}$ atom position was determined by the Fourier Difference and refined; the O-H distance is 0.80(4) $\AA$ and the angle between O-H bond and ( $\left(\begin{array}{lll}0 & 0 & 1\end{array}\right)$ plane is $\sim 6.55^{\circ}$.

\subsubsection{Phl-3T}

Several crystals of phlogopite $3 T$ were sampled from the hosting phengite Phe-3T, but only a few were suitable for measurements and structure refinements. Such specimens are about 
$200-400 \mu \mathrm{m}$ in length and width, and very thin $(<50 \mu \mathrm{m})$. A modest number of reflections were measured for $P h l-3 T$ and the structural refined parameters show large uncertainties, as shown in the figure of merit reported in Table 1, i.e. $R\left[\left|\mathrm{~F}_{\mathrm{o}}\right|>4 \sigma\left(\left|\mathrm{F}_{\mathrm{o}}\right|\right)\right]=8.50 \%$. Therefore structure constraints were introduced in the refinement strategy. The atomic displacement parameters have been constrained as follows: $\mathrm{U}_{i s o}(\mathrm{M} 1)=\mathrm{U}_{i s o}(\mathrm{M} 2)=\mathrm{U}_{i s o}(\mathrm{M} 3), \mathrm{U}_{i s o}(\mathrm{~T} 1)=$ $\mathrm{U}_{\text {iso }}(\mathrm{T} 2), \mathrm{U}_{\text {iso }}(\mathrm{O} 1)=\mathrm{U}_{\text {iso }}(\mathrm{O} 2)=\mathrm{U}_{\text {iso }}(\mathrm{O} 3)=\mathrm{U}_{\text {iso }}(\mathrm{O} 4)=\mathrm{U}_{\text {iso }}(\mathrm{O} 5)=\mathrm{U}_{\text {iso }}(\mathrm{O} 6)$ (Table 4). Conversely, the fractional coordinate distances were refined without any constraint, and the cation-anion distances were determined accordingly.

The structural results can be compared with those of the trigonal phlogopite samples from Traversella $(P h l-\mathrm{TR})$ and from Uganda $(P h l-\mathrm{UG})$. In $P h l$-TR $<\mathrm{M} 1-\mathrm{O}>$ is $2.079 \AA$, and 2.072(6) $\AA$ in Phl-UG. In both samples, <M1-O>s are not significantly different from $\langle\mathrm{M} 2-\mathrm{O}\rangle$ and $\langle\mathrm{M} 3-\mathrm{O}\rangle$. Conversely, the trigonal phlogopite sample investigated here, exhibits $\langle\mathrm{M} 1-\mathrm{O}\rangle$ of $2.245(3) \AA$, some $10 \%$ longer than $\langle\mathrm{M} 2-\mathrm{O}\rangle=1.991$ (8) $\AA$ and $\langle\mathrm{M} 3-$ $\mathrm{O}>=2.052(8) \AA$ (Table S4).

The occupancy factors of Fe-Al-Mg-Si in the tetrahedral and octahedral sites were not refined and the cations were arranged according to a completely disordered distribution. Only the number of electrons in the interlayer site was refined, as 16.9(2) $e$.

Comparing the distortion parameters (Table S5) with those reported for $P h l$-TR/UG, $P h l$ $3 T$ is more strained. Such an aspect is more marked in Phl-UG. The major distortions are not related to bond lengths, but mainly to angular values, thus suggesting that the structure strain is probably due to the $P h l-3 T$ 's growth process, which took place as a progressive substitution of the pre-existing framework of Phe-3T. 


\subsubsection{Phl-1M}

Only a few specimens of monoclinic quasi-exsolved phase were found in the hosting phengite. Using the largest one we performed single crystal X-ray diffraction experiments with a satisfactory number of reflections. The structure refinement in the S.G. $C 2 / m$ converged to $\mathrm{R} \sim 4.78 \%$ (Table $\mathrm{S} 3$ ).

The cell parameters $\left(a=5.3195(13) \AA, b=9.2117(12) \AA, c=10.210(3) \AA, \beta=100.04(2)^{\circ}\right.$, $V=492.7(2) \AA^{3}$; Table S4) are in excellent agreement with the ones of Phl-3T $(a=$ 5.318(1) $\left.\AA, c=30.21(2) \AA ; c_{(1 \mathrm{M})} \times \operatorname{sen} \beta(1 \mathrm{M})=30.16 \AA\right)$.

Average bond distances $\langle\mathrm{T}-\mathrm{O}\rangle_{1 \mathrm{M}}=1.652(1) \AA,\langle\mathrm{M}-\mathrm{O}\rangle_{1 \mathrm{M}}=2.074(1) \AA$ and $\langle\mathrm{I}-\mathrm{O}\rangle_{1 \mathrm{M}}=$ 3.159(1) $\AA$ are very similar to the corresponding values in Phl-3T sample (Tables S3 and S4). The two M-O distances are meaningfully different from one another $(\langle\mathrm{M} 1-\mathrm{O}\rangle=$ 2.088(1); $\langle\mathrm{M} 2-\mathrm{O}\rangle=2.061(1) \AA)$, but the refined electron content $(14.17(14)$ and 14.18(12) $e$ for M1 and M2, respectively) does not indicate any cation order.

Phl- $1 M$ yields bond-lengths, bond-angles and distortion parameters $\left(\alpha=8.00^{\circ}, \Delta \mathrm{z}=0.01 \AA\right.$; $\Delta_{\mathrm{TM}}=0.44 \AA, \mathrm{BLD}_{\mathrm{M} 1}=0.76 \%, \mathrm{BLD}_{\mathrm{M} 2}=0.80 \%, \mathrm{~J}_{\mathrm{M} 1}=0.00^{\circ}$ and $\mathrm{J}_{\mathrm{M} 2}=0.88^{\circ} ;$ Table S5) in agreement with those reported in literature on phlogopite $1 M$ (Brigatti and Guggenheim, 2002).

\section{Discussion}

\subsection{Mass balance calculation}

The rock containing the studied micas and quartz is a thick metamorphic vein, similar to those commonly observed in the Sulu UHP terrane. A not-weighted mass balance calculation (Wright and Doherty, 1970) was used to provide the best match between the 
sampled mineralogical assemblage and fluid alkali-alumino-silicate components that mirror the bulk rock averaged compositions of the Sulu-vein $(A S V)$, reduced to an anhydrous major oxides system (Table 2):

$x_{1} P h e-3 T+x_{2}$ quartz $+x_{3} P h l-3 T+x_{4} P h l-1 M+x_{5} \mathrm{~K}$-feldspar $=1 A S V$

where $x_{i}$ represents the $i$-phase proportion. The solution is (least square residuum, $r^{2}=0.8$ ):

0.574 Phe-3T +0.488 quartz $+(-0.049) P h l-3 T+(-0.002) P h l-1 M+(-0.001)$ K-feldspar $=1$ $A S V$

Eq.(2) demonstrates that $A S V$ accounts for a phengite-quartz based rock and the occurrence of phlogopite micas can be explained as an effect of disproportion in combination with a supply of elements, i.e. $\mathrm{Mg}, \mathrm{Al}$ and $\mathrm{K}$, most probably solute components of alkali-aluminosilicate aqueous solutions at high pressure rock-fluid interactions.

Such results agree with the observed petrographic characteristics of the vein fragment from which the studied micas were extracted: (1) phengite and quartz are comparably proportioned in the rock; (2) the negative phase proportion coefficients suggest that phlogopites are per force scarce and only occur as quasi-exsolved phases, in combination with an elemental supply from alkali-alumino-silicate high pressure fluids; (3) K-feldspar is modally absent in the fragment, as the negligible resulting negative proportion (i.e. 0.001) suggests.

\section{$4.2 \quad P-T-X$ Equilibrium phases in an open system}

The coexistence of $P h e-3 T, P h l-3 T$ and $P h l-1 M$ micas cannot be reduced to bare exsolving reactions in a closed system and a contribution from an "external chemical supplier", i.e. a "reservoir", has to be taken into account (eq.(2)). Therefore, the reactions were modelled 
in terms of an open system. Following Merli et al. (2017), the "reservoir" is now seen as a matter exchanger, whose composition, addressed by $\operatorname{Res}(\mathrm{A} / \mathrm{B})$, encompasses all the potential solids and fluids taking part in the petrogenetic reactions, but micas and quartz. $\mathrm{A} / \mathrm{B}$ are used to indicate a specific chemical condition of the reservoir. In this case, we modelled the reaction process from phengite to phlogopite with the following transformation:

phengite $+\operatorname{Res}(\mathrm{A})=$ phlogopite $+\lambda$ quartz $+\operatorname{Res}(\mathrm{B})$

where $\lambda$ is related to the amount of quartz exsolved from the reacting phengite, i.e. $\lambda \approx 0.46$.

The equilibrium conditions of the assemblage require that

$$
\begin{gathered}
\Delta G=G(\text { phengite })+G[\operatorname{Res}(\mathrm{A})]-G(\text { phlogopite })-G[\operatorname{Res}(\mathrm{B})]-\lambda G(\text { quartz })= \\
G(\text { phengite })-G(\text { phlogopite })-\lambda G(\text { quartz })+\{G[\operatorname{Res}(\mathrm{A})]-G[\operatorname{Res}(\mathrm{B})]\}= \\
G(\text { phengite })-G(\text { phlogopite })-\lambda G(\text { quartz })+\delta G[\operatorname{Res}]=0,
\end{gathered}
$$

where $G$ is the molar Gibbs energy of a given phase, i.e. its chemical potential, and $\delta G[R e s]$ is the molar Gibbs energy difference between $\operatorname{Res}(\mathrm{A})$ and $\operatorname{Res}(\mathrm{B})$. Phengite and phlogopite refer to $P h e-3 T$ and $P h l-3 T$, respectively.

The Gibbs energy of a phase at given $P-T$ conditions can be determined by two distinct integrations, one along an isobar at $P_{0}$ and the other along an isotherm at $T$, i.e.

$G(P, T)=G\left(P_{0}, T_{0}\right)-\int_{T_{0}}^{T} S\left(P_{0}, T^{\prime}\right) d T^{\prime}+\int_{P_{0}}^{P} V\left(P^{\prime}, T\right) d P^{\prime}$

where $P_{0}$ and $T_{0}$ are in general reference pressure and temperature (for explicit calculations refer to Pavese and Diella, 2007), here corresponding to room pressure and temperature. Equation (5) can be written as

$\Delta G(P, T)=\Delta G\left(P_{0}, T_{0}\right)+\Delta I_{T-T_{0}}+\Delta I_{T-T_{0}, \text { config }}+\Delta I_{P-P_{0}}$ where $\Delta G\left(P_{0}, T_{0}\right)$ is the formation energy with respect to the standard state of the constituent oxides. $\Delta I_{P-P_{0}}$ is due to the solid phases of eq. (4), i.e. micas and quartz, and it 
can be determined by means of the equations of state of the involved minerals. We used a third order Birch-Murnaghan $P-V-T$ relationship and thermo-elastic parameters from Amisano-Canesi et al. (1994); Angel et al. (1997); Chon et al. (2003, 2006 ); Comodi et al. (1999); Curetti et al. (2006); Gatta et al. (2009, 2011), Gemmi et al. (2008). Hazen and Finger (1978); Russell and Guggenheim (1999); Takeda and Morosin (1975) and Ventruti et al. (2009).

$\Delta G\left(P_{0}, T_{0}\right)+I_{T-T_{0}}$ were estimated by the reaction:

$\frac{1}{2}$ muscovite $+\frac{1}{4}$ celadonite $+\frac{1}{4} \mathrm{Fe}-$ celadonite +1.75 periclase +0.75 wüstite $=$ $\frac{2}{3}$ phlogopite $+\frac{1}{3}$ annite $+\frac{1}{2}$ corundum $+\frac{1}{2}$ quartz

taking the Gibbs energy of formation and heat capacity at constant pressure from Holland and Powell (1998). The $\Delta G\left(P_{0}, T_{0}\right)+I_{T-T_{0}}$ is modest and weakly dependent on $T$ in the investigated $770-1200 \mathrm{~K}$ thermal range. In was therefore approximated by a constant as large as $13 \mathrm{~kJ} / \mathrm{mol}$. However, taking into account the high degree of approximation, we assumed a confidence range from 10 to $15 \mathrm{~kJ} / \mathrm{mol}$, and explored its limits. Lastly, $\Delta I_{T-T_{0}, \text { config }}$ is due to the configuration contribution to entropy, $S_{\text {config }}$, which is calculated as follows:

$$
S_{\text {config }}=-\mathrm{R} \sum_{j=1}^{\text {sites }} \sum_{\alpha=1}^{\text {chemical species }} p_{j, \alpha} \ln \left(p_{j, \alpha}\right)
$$

where $\mathrm{R}$ is the universal gas constant and $p_{j, \alpha}$ is the occupancy factor of the $\alpha$-species at the $j^{\text {th }}$-sites. In figure 6 we display the $P-T$ loci $\left(\mathrm{GPa}\right.$ and $\left.{ }^{\circ} \mathrm{C}\right)$ of equilibrium for reaction (4), with $\Delta G\left(P_{0}, T_{0}\right)+I_{T-T_{0}}$ equal to 10 and $15 \mathrm{~kJ} / \mathrm{mol}$, respectively.

The intersection between the equilibrium $P-T$ locus and the supposed $P-T$ metamorphic path of OH-rich quartzite from Sulu UHP terrane from Frezzotti et al. (2007) occurs at $P \approx$ 2.4 $\pm 0.2 \mathrm{GPa}$ and $T \approx 700{ }^{\circ} \mathrm{C}$. Such a result is consistent with the observation of Hermann 
and Green (2001), if the phengite existence curve of the quoted authors is extrapolated to $700{ }^{\circ} \mathrm{C}$.

On the basis of petrological data, stable isotope geothermometry and theoretical phase relationships of quartzites from Sulu terrane, the UHP fluids composition estimated by Frezzotti et al. (2007) is an intermediate alkali-alumino-silicate aqueous solutions $\left(\mathrm{H}_{2} \mathrm{O}\right.$ $\sim 50 \mathrm{wt} \%$ ), that constrains the metamorphic peak at $P \sim 3.5 \mathrm{PGa}$ and $T \sim 780{ }^{\circ} \mathrm{C}$.

The obvious compositional similarity between the quartzites investigated by Frezzotti et al. (2007) and the Sulu vein of this study allowed us to state that the calculated P-T conditions for phlogopite growth in a $\mathrm{SiO}_{2}$ oversaturated system indicate at a region that reflects early stages of exhumation, close to the metamorphic peak (Fig. 6).

\section{Conclusions}

The main purpose of this work was to study the rare coexistence of dioctahedral mica and trioctahedral quasi-exsolutions observed in a thick quartz+phengite metamorphic vein found in the northern part of Sulu UHP metamorphic terrane, of Donghai County (eastern China).

The process leading to such an assemblage is described as a "quasi-exsolution" process and it is constituted by non-isochemical exsolution . The composition change is due to an external supplier.

The reaction process from phengite to phlogopite favours /requires the exsolution of quartz. Because of the trigonal structure provided from phengite, the quasi-exsolved phlogopite crystallised as $3 T$-polytype, which is unusual for trioctahedral micas.

Mass balance calculations suggest that the phengite-quartz based rock and the occurrence of phlogopite micas can be explained as an effect of disproportion in combination with a 
supply of elements, i.e. $\mathrm{Mg}, \mathrm{Al}$ and $\mathrm{K}$, from alkali-alumino-silicate high pressure fluids, that mirror the bulk Sulu vein composition.

The calculated equilibrium $P-T$ locus of phengite-phlogopite-quartz reaction intersects the $P-T$ metamorphic path at $P \approx 2.4 \pm 0.2 \mathrm{GPa}$ and $T \approx 700{ }^{\circ} \mathrm{C}$, indicating an early stage of exhumation, close to the metamorphic peak of the Sulu UHP terrane.

\section{Acknowledgements}

The studied phengite was collected in 2000, during a field expedition in the Sulu orogene, organised by Prof. Xu Shutong in the framework of a Chinese-Italian cooperation project (R.C The authors thank the Editor Marco Scmbelluri, Patrizia Fumagalli and anonymous reviewer for their positive comments. The authors would like to thank the "Compagnia di San Paolo" of Turin, Italy, for supporting the TGA measurements. L.N would like to thank the Department of Chemical Science, University of Padua, for allowing the free use of Mössbauer spectrometer.

The paper benefited of the English language editing provided by Barbara Galassi (Brighton, U.K)

Part of this research was supported by MIUR-2015 20158A9CBM Grant (C.B).

\section{References}

Aldridge, L.P., Finch, J, Gainsford, A.R., Tennant, W.C., Childs, C.W., 1987. Electricfield gradient in muscovites. American Mineralogist 72, 528-536.

Amisano-Canesi, A., Chiari, G., Ferraris, G., Ivaldi, G., Soboleva, S.V., 1994. Muscoviteand phengite-3T: crystal structure and conditions of formation. European Journal of Mineralogy 6, 489-496. 
Angel, R.J., Allan, D.R., Miletich, R., Finger, L.W., 1997. The use of quartz as an internal pressure standard in high pressure crystallography. Journal of Applied Crystallography 30, 461-466.

Brigatti, F., Guggenheim, S., 2002. Mica crystal chemistry and the influence of pressure, temperature, and solid solution on atomistic models. Reviews in Mineralogy and Geochemistry 46, 1-97.

Castelli, D., Rolfo, F., Compagnoni, R., Xu, S.T., 1998. Metamorphic veins with kyanite, zoisite and quartz in the Zhu-Jia-Chong eclogite, Dabie Shan, China. Island Arc 7(1-2), 159-173.

Chon C-M, Kim SA, Moon H-S, 2003. Crystal structure of biotite at high temperatures and of heat-treated biotite using neutron powder diffraction. Clays and Clay Minerals $51,519-528$.

Chon, C.-M., Lee, C.-K., Song, Y., Kim, S.-A., 2006. Structural changes and oxidation of ferroan phlogopite with increasing temperature: in situ neutron powder diffraction and Fourier transform infrared spectroscopy, Physics and Chemistry of Minerals 33(5), 289-299.

Comodi, P., Zanazzi, P.F., Weiss, Z., Rieder, M., Drábek, M., 1999. “Cs-ferri-tetraannite": high-pressure and high-temperature behavior of a potential nuclear waste disposal phase. American Mineralogist 84, 325-332.

Compagnoni, R., Engi, M., Regis, D., 2014. Val d'Aosta section of the Sesia Zone: multistage $\mathrm{H} P$ metamorphism and assembly of a rifted continental margin. $10^{\text {th }}$ Int. Eclogite Conf., Syn-Conference Excursion, 5 September 2013, GFT - Geological Field Trips, 6 (1.2), 1-44. ISSN: 2038-4947. (DOI 10.3301/GFT.2014.02) http://www.isprambiente.gov.it/it/pubblicazioni/periodici-tecnici/geological-field- 
trips/valle-daosta-section-of-the-sesia-zone.

Cong, B.-L., Wang, Q.C., Zhai, M., Zhang, R.Y., Zhao, Z.Y., Ye, K., 1994. Ultrahighpressure metamorphic rocks in the Dabishan-Sulu Region of China. Island Arc 3, $135-150$.

Curetti, N., Levy, D., Pavese, A., Ivaldi, G., 2006. Elastic properties and stability of coexisting 3T and 2M1 phengite polytypes. Physics and Chemistry of Minerals $32(10), 670-678$.

Curetti, N., Ferraris, G., Ivaldi, G., 2008. Correlation between crystallization pressure and structural parameters of phengites. American Mineralogist 93, 451-455.

Deng, L.-P., Liu, Y.-C., Gu, X.-F., Groppo, C., Rolfo, F., 2017. Partial melting of ultrahigh-pressure metamorphic rocks at convergent continental margins: Evidences, melt compositions and physical effects, Geoscience Frontiers. http://dx.doi.org/10.1016/j.gsf.2017.08.002

Desmons, J., O’Neill, J.R., 1978. Oxygen and hydrogen isotope compositions of eclogites and associated rocks from the eastern Sesia Zone (Western Alps, Italy). Contributions to Mineralogy and Petrology 67, 79-85.

Droop, G.T.R., Lombardo, B., Pognante, U., 1990. Formation and distribution of eclogite facies rocks in the Alps. In: D.A. Carswell, (Ed.) Eclogite Facies Rocks. Glasgow, Blackie, 225-259.

Ferrando, S., Frezzotti, M.L., Dallai, L., Compagnoni, R., 2005. Fluid-rock interaction in UHP phengite-kyanite-epidote eclogite from the Sulu Orogen, Eastern China. International Geology Review 47, 750-774.

Ferraris, G., Ivaldi, G., 2002. Micas: crystal chemistry and metamorphic petrology. Reviews in Mineralogy and Geochemistry 46, 117-153.

Ferraris, G., Ivaldi, G., Nespolo, M., Takeda, H., 1995. On the stability of dioctahedral 
micas. Terra Abstract (suppl. N.1 Terra Nova) 7, 289.

Ferraris, C., Chopin, C., Wessicken, R., 2000. Nano- to micro-scale decompression products in ultrahigh-pressure phengite: HRTEM and AEM study, and some petrological implications. American Mineralogist 85, 1195-1201.

Ferraris, C., Grobety, B., Wessicken, R., 2001. Phlogopite exsolution within muscovite: a first evidence for a higher-temperature re-equilibration, studied by HRTEM and AEM techniques. European Journal of Mineralogy 13, 15-26.

Ferrow, E.A., London, D., Goodman, K.S., Veblen, D.R., 1990. Sheet silicates of the Lawler Peak granite, Arizona: chemistry, structural variations, and exsolution. Contributions to Mineralogy and Petrology 105, 491-501.

Finch, J., Gainsford, A.R., Tennant, W.C., 1982. Polarized optical absorption and ${ }^{57} \mathrm{Fe}$ Mössbauer study of pegmatitic muscovite. American Mineralogist 67, 59-68.

Frank, W., Hock, V., Miller, C., 1986. Metamorphic and tectonic history of the Central Tauern Window. In: H.W. Flugel, P. Faupl (Eds.), Geodynamics of the Eastern Alps, Deuticke, Vienna, 34-54.

Frezzotti, M.L., Ferrando, S., Dallai, L., Compagnoni, R., 2007. Intermediate alkalialumino-silicate aqueous solutions released by deeply-subducted continental crust: fluid evolution in UHP OH-rich topaz-kyanite-quartzites from Donghai County (Sulu, China). Journal of Petrology 48, 1219-1241.

Gatta, G.D., Rotiroti, N., Pavese, A., Lotti, P., Curetti, N., 2009. Structural evolution of a 3T phengite mica up to $10 \mathrm{GPa}$ : an in-situ single-crystal X-ray diffraction study. Zeitschrift für Kristallographie 224, 302-310.

Gatta, G.D., Merlini, M., Rotiroti, N., Curetti, N., Pavese, A., 2011. On the crystal chemistry and elastic behavior of a phlogopite 3T. Physics and Chemistry of 
Minerals 38, 655-664.

Gemmi, M., Merlini, M., Pavese, A., Curetti, N., 2008. Thermal expansion and dehydroxylation of phengite micas. Physics and Chemistry of Minerals 35(7), 367379.

Goodman, B.A., 1976. The Mössbauer spectrum of a ferrian muscovite and its implications in the assignment of sites in dioctahedral micas. Mineralogical Magazine 40, 513517.

Gresens, R.L., Stensrud, H.L., 1971. Chemical, optical, and X-ray analysis of an unusual muscovite-biotite intergrowth. Lithos 4, 63-69.

Hazen, R.M., Finger, L.W., 1978. The crystal structures and compressibilities of layer minerals at high pressure. II Phlogopite and Chlorite. American Mineralogist 63, 293-296.

Hermann, J., Green, D.H., 2001. Experimental constraints on high pressure melting in subducted crust. Earth and Planetary Science Letters 188, 149-168.

Hermann, J., Rubatto, D., 2009. Accessory phase control on the trace element signature of sediment melts in subduction zones. Chemical Geology 265, 512-526.

Hirajima, T., Nakamura, D., 2003. The Dabie Shan-Sulu orogeny. In: D.A., Carswell and R., Compagnoni (Eds.), Ultrahigh-pressure metamorphism. E.M.U. Notes in Mineralogy 5, 105-144. Eötvös University Press, Budapest.

Holland, T.J.B., Powell, R., 1998. An internally consistent thermodynamic data set for phases of petrological interest. Journal of Metamorphic Geology 16, 309-343.

Ivaldi, G., Ferraris, G., Curetti, N., Compagnoni, R., 2001. Coexisting 3T and 2M1 polytypes of phengite from Cima Pal (Val Savenca, western Alps): Chemical and polytypic zoning and structural characterisation. European Journal of Mineralogy 
13, 1025-1034.

Lester, J.G., 1946. Inclusions in muscovite from Mitchell Creek Mine, Upson Country, Georgia. American Mineralogist 31, 77-81.

Li X.-P., Li Y.-L., Shu G.-M., 2005. Breakdown of lawsonite subsequent to peak UHP metamorphism in the Dabie terrane and its implication for fluid activity. Chinese Science Bulletin 50(13), 1366-1372.

Liu, Y.-C., Deng, L., Gu, X., Groppo, C., Rolfo, F., 2015. Application of Ti-in-zircon and $\mathrm{Zr}$-in-rutile thermometers to constrain high-temperature metamorphism in eclogites from the Dabie orogen, central China. Gondwana Research 27, 410-423.

Massonne, H.-J., Szpurka, Z., 1997. Thermodynamic properties of white micas on the basis of high-pressure experiments in the systems $\mathrm{K}_{2} \mathrm{O}-\mathrm{MgO}-\mathrm{Al}_{2} \mathrm{O}_{3}-\mathrm{SiO}_{2}-\mathrm{H}_{2} \mathrm{O}$ and $\mathrm{K}_{2} \mathrm{O}-$ $\mathrm{FeO}-\mathrm{Al}_{2} \mathrm{O}_{3}-\mathrm{SiO}_{2}-\mathrm{H}_{2} \mathrm{O}$. Lithos 41, 229-250.

Mattinson C.G., Zhang R-Y., Tsujimori T., Liou J.G., 2004. Epidote-rich talc-kyanitephengite eclogites, Sulu terrane, eastern China: P-T-fO2 estimates and the significance of the epidote-talc assemblage in eclogite. American Mineralogist 89(11-12), 1772-1783.

Merli, M., Pavese, A., Curetti, N., 2009. Maximum entropy method: an unconventional approach to explore observables related to the electron density in phengites. Physics and Chemistry of Minerals 36, 19-28.

Merli, M., Bonadiman, C., Diella, V., Sciascia, L., Pavese, A., 2017. Fe-periclase reactivity at Earth's lower mantle conditions: Ab-initio geochemical modelling. Geochimica et Cosmochimica Acta 214, 14-29.

Monier, G., Robert, J.L., 1986a. Muscovite solid solutions in the system $\mathrm{K}_{2} \mathrm{O}-\mathrm{MgO}-\mathrm{FeO}-$ $\mathrm{Al}_{2} \mathrm{O}_{3}-\mathrm{SiO}_{2}-\mathrm{H}_{2} \mathrm{O}$ : an experimental study at $2 \mathrm{kbar} \mathrm{P}_{\mathrm{H} 2 \mathrm{O}}$ and comparison with natural 
Li-free white micas. Mineralogical Magazine 50, 257-266.

Monier, G., Robert, J.L., 1986b. Evolution of the miscibility gap between muscovite and biotite solid solutions with increasing lithium content: an experimental study in the system $\mathrm{K}_{2} \mathrm{O}-\mathrm{Li}_{2} \mathrm{O}-\mathrm{MgO}-\mathrm{FeO}-\mathrm{Al}_{2} \mathrm{O}_{3}-\mathrm{SiO}_{2}-\mathrm{H}_{2} \mathrm{O}-\mathrm{HF}$ at $600^{\circ} \mathrm{C}, 2$ kbar $\mathrm{P}_{\mathrm{H} 2 \mathrm{O}}$ : comparison with natural lithium micas. Mineralogical Magazine 50, 641-651.

Pavese, A., Diella, V., 2007. Uncertainties on elastic parameters and occupancy factors: how do they affect the accuracy of the calculated Gibbs energy of minerals at $(\mathrm{P}, \mathrm{T})$ conditions? The case of $3 \mathrm{~T}$ - versus $2 \mathrm{M}_{1}$ phengite. Physics and Chemistry of Minerals 34(9), 637-645.

Pavese, A., Diella, V. 2013. How stacking disorder can conceal the actual structure of micas: the case of phengites. DOI:10.1007/s00269-013-0568-6. Physics and Chemistry of Minerals 40, 375-386.

Pavese., A., Ferraris, G., Pischedda, V., Ibberson, R., 1997. Cation Site ordering in phengite 3T from Dora Maira massif (western Alps): a variable-temperature neutron powder diffraction study. European Journal of Mineralogy 9, 1183-1190.

Pavese, A., Ferraris, G., Pischedda, V., Mezouar, M., 1999. Synchrotron powder diffraction study of phengite 3T from Dora Maira massif: P-V-T equation of state and petrological consequences. Physics and Chemistry of Minerals 26, 460-467.

Pavese, A., Ferraris, G., Pischedda, V., Radaelli, P., 2000. Further study of cation ordering in phengite 3T by neutron powder diffraction. Mineralogical Magazine 64, 11-18. 
Pavese, A., Ferraris, G., Pischedda, V., Fauth, F., 2001. M1-site occupancy in 3T and $2 \mathrm{M}_{1}$ phengites by low temperature neutron powder diffraction: Reality or artefact? European Journal of Mineralogy 13, 1071-1078.

Pavese, A., Curetti, N., Ferraris, G., Ivaldi, G., Russo, U., Ibberson, R., 2003 a. Deprotonation and order-disorder reactions as a function of temperature in a phengite 3T (Cima Pal, western Alps) by neutron diffraction and Mössbauer spectroscopy. European Journal of Mineralogy 15, 357-363.

Pavese, A., Levy, D., Curetti, N., Diella, V., Sani, A., 2003b. Equation of state and compressibility of phlogopite by in-situ high pressure X-ray diffraction experiment. European Journal of Mineralogy 15, 455-463.

Pavese, A., Curetti, N., Diella, V., Levy, D., Dapiaggi, M., Russo, U., 2007. $P-V$ and $T-V$ Equations of State of natural biotite: an in-situ high pressure and high temperature powder diffraction study, combined with Mössbauer spectroscopy. American Mineralogist 92(7), 1158-1164.

Petricek, V., Dusek, M., Palatinus, L., 2014. Crystallographic Computing System JANA2006: General features. Zeitschrift für Kristallographie 229(5), 345-352.

Poli, S., Fumagalli P., 2003. Mineral assemblages in ultrahigh pressure metamorphism: A review of experimentally determined phase diagrams. In: D.A. Carswell and R. Compagnoni (Eds.) Ultrahigh-pressure metamorphism. E.M.U. Notes in Mineralogy 5, 307-340. Eötvös University Press, Budapest.

Rieder, M., Cavazzini, G., D’Yakonov, Yu.S., Frank-Kamenetskii, V.A., Gottardi, G., Guggenhein, S., Koval, P.V., Müller, G., Neiva, A.M.R., Radoslovich, E.W., Robert, J.L., Sassi F.P., Takeda, H., Weiss Z., Wones, D.R., 1998. Nomenclature of the micas. The Canadian Mineralogist 36, 905-912. 
617 Geological Society of America, 1991: Rock color chart with genuine Munsell ${ }^{\mathrm{R}}$ color chips. Boulder, Colo Ed.

619

620

621

622

623

624

625

626

627

628

629

630

631

632

633

634

635

636

637

638

639

640

Russell, R.L., Guggenheim, S., 1999. Crystal structures of near-end-member phlogopite at high temperatures and heat-treated Fe-rich phlogopite: The influence of the $\mathrm{O}, \mathrm{OH}$, F site. The Canadian Mineralogist 37, 711-720.

Sassi, F.P., Guidotti, C., Rieder, M., De Pieri, R., 1994. On the occurrence of metamorphic 2M1 phengites: some thoughts on polytypism and crystallization condition of $3 \mathrm{~T}$ phengites. European Journal of Mineralogy 6, 151-160.

Schingaro, E., Lacalamita, M., Scordari, F., Mesto, E., 2013. 3T-phlogopite from Kasenyi kamafugite (SW Uganda): EPMA, XPS, FTIR and SCXRD study. American Mineralogist 98, 709-717.

Schmidt, M.W., Poli, S., 1998. Experimentally based water budgets for dehydrating slabs and consequences for arc magma generation. Earth and Planetary Science Letters $163,361-379$.

Schmidt, M. W., Vielzeuf, D., Auzanneau, E., 2004. Melting and dissolution of subducting crust at high pressures: the key role of white mica. Earth and Planetary Science Letters 228, 65-84.

Shabani, A.A.T., Rancourt, D.G., Lalonde, A.E., 1998. Determination of cis and trans Fe2+ populations in $2 \mathrm{M}(1)$ muscovite by Mossbauer spectroscopy. Hyperfine Interactions, 117, 117-129.

Sheldrick, G.M., 1997. SHELXL-97, Program for the Refinement of Crystal Structure; University of Göttingen, Germany.

Smyth, J.R., Jacobsen, S.D., Swope, R.J., Angel, R.J., Arlt, T., Domanik, K., Holloway, J.R., 2000. Crystal structures and compressibilities of synthetic $2 \mathrm{M}_{1}$ and $3 \mathrm{~T}$ 

phengite micas. European Journal of Mineralogy 12(5), 955-963.

Takeda, H., Morosin, B., 1975. Comparison of observed and predicted structural parameters of mica at high temperature. Acta Crystallographica B31, 2444-2452.

Thomsen, T.B., Schmidt, M.W., 2008. The Biotite to Phengite Reaction and Micadominated Melting in Fluid+Carbonate-saturated Pelites at High Pressures. Journal of Petrology 49, 1889-1914.

Tutti, F., Dubrovinsky, LS., Nygren, M., 2000. High-temperature study and thermal expansion of phlogopite. Physics and Chemistry of Minerals 27(9), 599-603.

Ventruti, G., Levy, D., Pavese, A., Scordari, F., Suard, E., 2009. High-temperature treatment, hydrogen behaviour and cation partitioning of a Fe-Ti bearing volcanic phlogopite by in situ neutron powder diffraction and FTIR spectroscopy. European Journal of Mineralogy 21(2), 385-396.

Weiss, Z., Rieder, M., Smrcok, L., Petricek, V., Bailey, S.W., 1993. Refinement of the crystal structures of two "protolithionites". European Journal of Mineralogy 5, 493-502.

Wright, T.L., Doherty, P.C., 1970. A linear programming and least-squares computer method for solving petrologic mixing problems. Geological Society of America Bulletin 81, 1995-2008.

Xu, H.J., Ye, K., Zhang, J.F., 2012. Temperature of prograde metamorphism, decompressional partial melting and subsequent melt fractional crystallization in the Weihai migmatitic gneisses, Sulu UHP terrane: constraints from Ti-in-zircon thermometer. Journal of Earth Sciences 23, 813-827.

Zanazzi, P.F. and Pavese, A., 2002. Behavior of micas at high pressure and high temperature. Reviews in Mineralogy and Geochemistry 46, 98-116. 
665 Zhang, R. Y., Hirajima, T., Banno, S., Cong, B., Liou, J. G., 1995. Petrology of ultrahighpressure rocks from the southern Sulu region, eastern China. Journal of Metamorphic Geology 13, 659-675.

668 geochronology of zircon in garnet peridotite from Sulu UHP terrane, China: implications for mantle metasomatism and subduction-zone UHP metamorphism. Earth and Planetary Science Letters 237, 729-743.

Zhang, Z.M., Xiao, Y.L., Liu, F., Liou, J.; Hoefs, J., 2005. Petrogenesis of UHP metamorphic rocks from Qinglongshan, Southern Sulu, East-Central China. Lithos $81,189-207$

Zheng, Y., Zhou, J.-B., Wu, Y.-B., Xie, Z., 2005. Low-grade metamorphic rocks in the Dabie-Sulu orogenic belt: a passive-margin accretionary wedge deformed during continent subduction. International Geology Review 47, 851-871. 
Figure 1. Simplified geologic sketch map of the Sulu orogen showing major tectonic units. YQWF, Yantai-Qingdao-Wulian fault White circles mark the location of labelled towns (from Mattinson et al., 2004 and Zhang et al., 2005, modified); The phengite+quartz metamorphic vein was excavated at Qinglongshan (evidenced in the map), in the Donghai County.

Figure 2. Optical micrograph (plane polarised light) of Fe-phlogopite quasi-exsolution (brown colour) developed in pyramidal form (its thickness increases toward the centre), with several evident growth stages.

Figure 3. Optical micrographs of mica quasi-exsolutions and quartz crystals in trigonal phengite observed under plane polarised (a) light and crossed polarised (b) lights, respectively. The quasi-exsolution is apparent in (a) (darker portions) while the micaquartz reaction is amplified in (b) (white portions).

Figure 4. Mössbauer spectrum collected on Phe-3T sample. The peaks are fitted with three doublets and they indicate that $57(1) \%$ of the total $\mathrm{Fe}$ is trivalent, 43(1)\% bivalent (parameters in Table S1).

Figure 5. Changes of chemical composition from Phe-3T to Phl-3T; (a) schematic representation of the analysed sample and location of the analysis points. (b) The histogram reports the variation by weight $\%$ of the principal oxides; approaching the quasiexsolved phases, $\mathrm{Si}$ and $\mathrm{Al}$ decrease, while $\mathrm{Fe}$ and $\mathrm{Mg}$ increase. 
703 Figure 6. Pressure-temperature loci of equilibrium for the phengite-phlogopite-quartz reaction (eq. 2). The cases of $\Delta G\left(P_{0}, T_{0}\right)+\mathrm{I}_{T-T_{0}}$ equal to 10 and $15 \mathrm{~kJ} / \mathrm{mol}$ are shown.

705 The blue line represents the Sulu UHP-HP metamorphic $P-T$ evolution stages from the 706 prograde metamorphic peak at $P \sim 3.5 \mathrm{GPa}$ and $T \sim 780{ }^{\circ} \mathrm{C}$ (large blue square) to the late 707 stage of exhumation $P \sim 0.3 \mathrm{GPa}$ and $T \sim 400{ }^{\circ} \mathrm{C}$ (small blue square). The intersection of 708 the calculated equilibrium $P-T$ locus of phengite-phlogopite-quartz reaction with the 709 metamorphic path (from Frezzotti et al., 2007) is marked by the blue box. 
Click here to download high resolution image

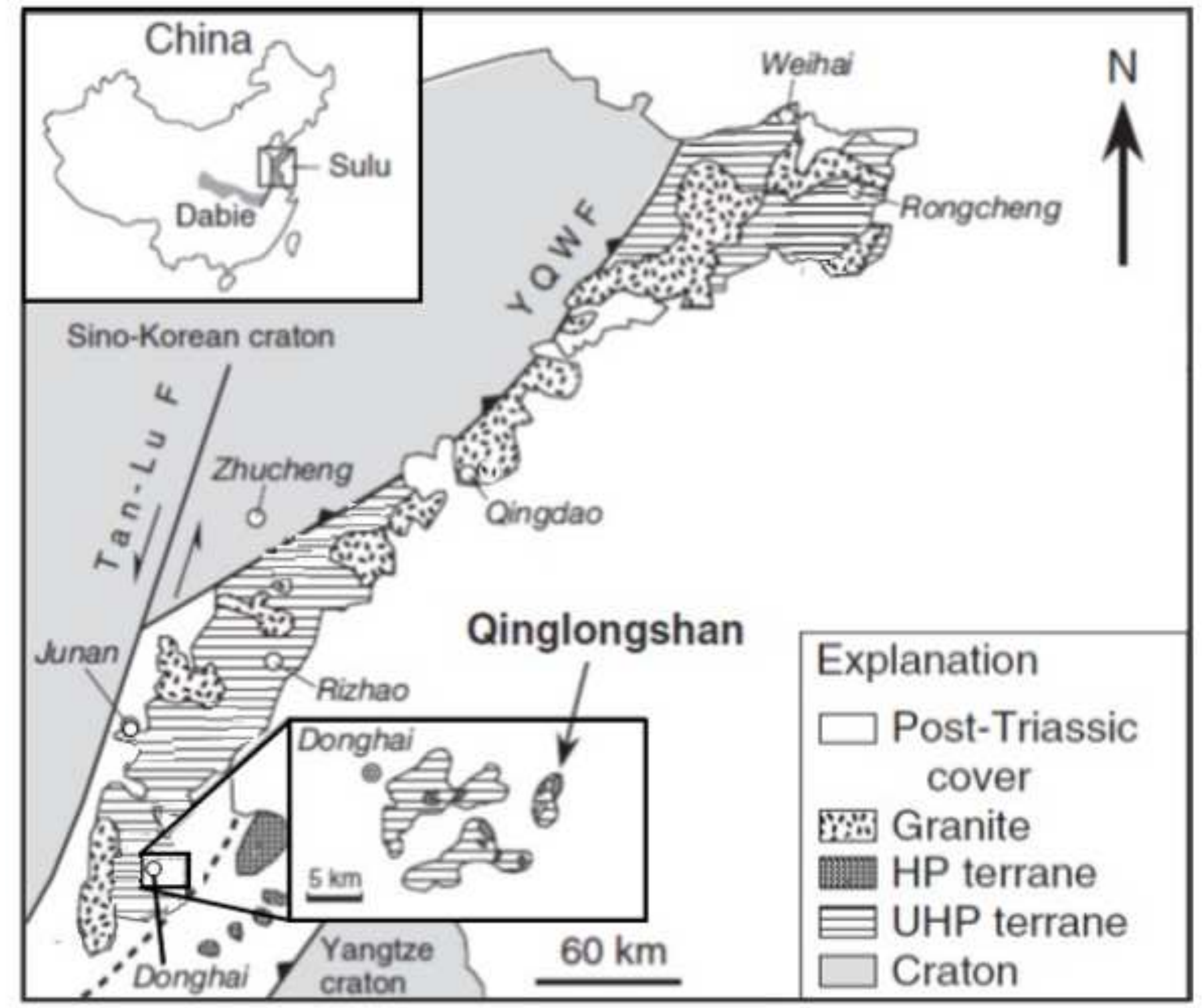




\section{Figure 2}

Click here to download high resolution image

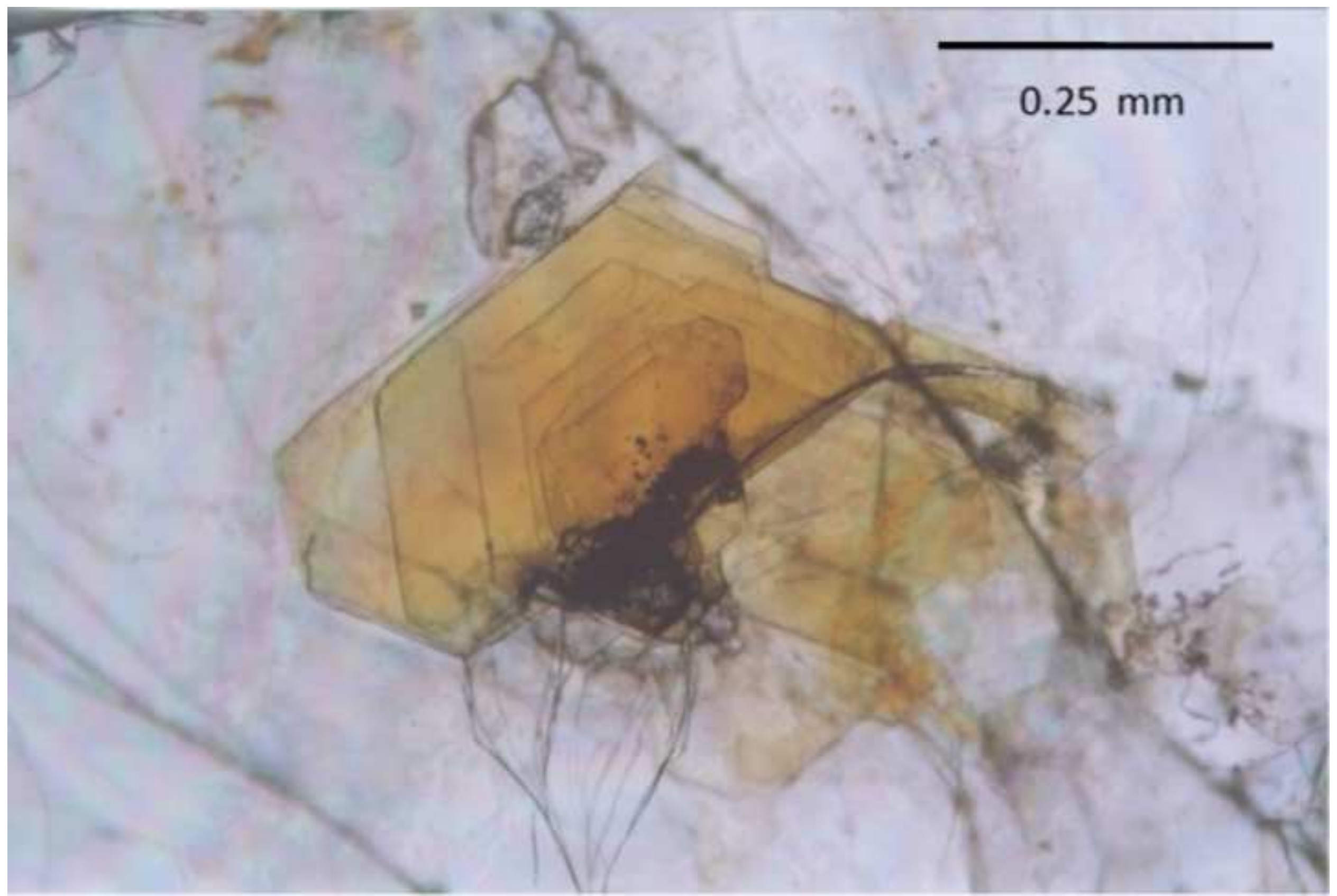




\section{Click here to download high resolution image}
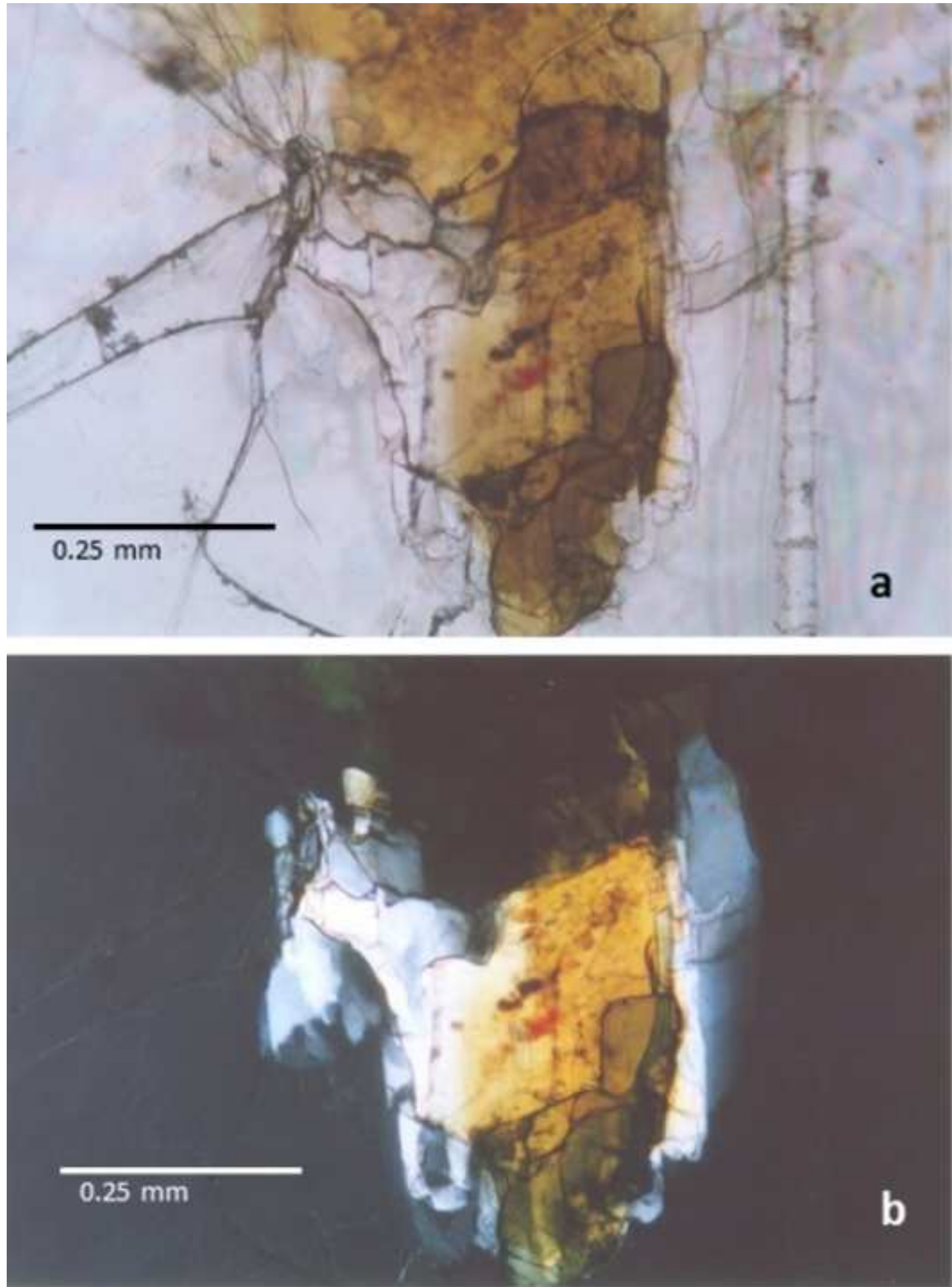


\section{Figure 4}

Click here to download high resolution image

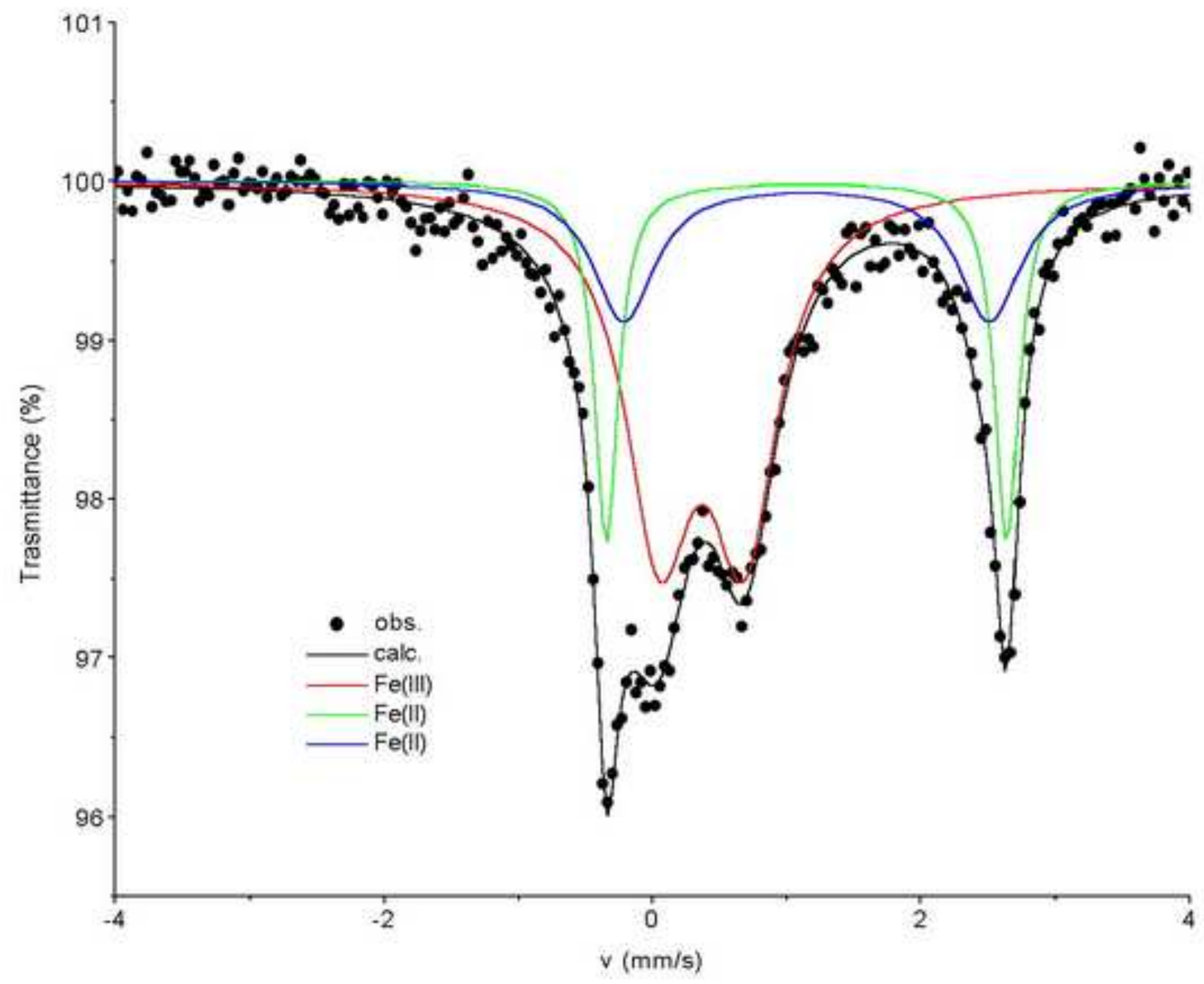


Click here to download high resolution image

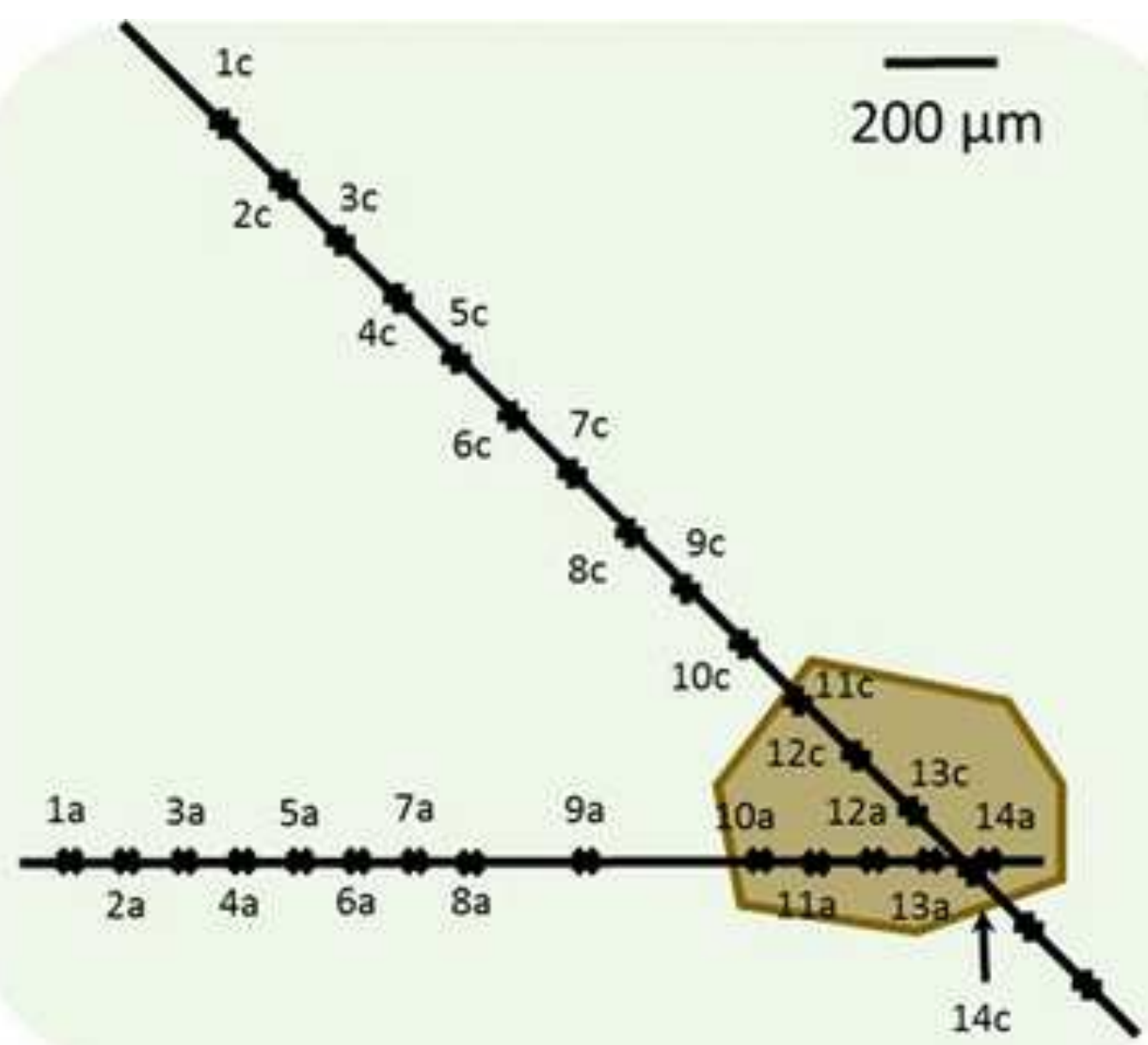

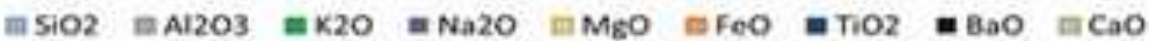

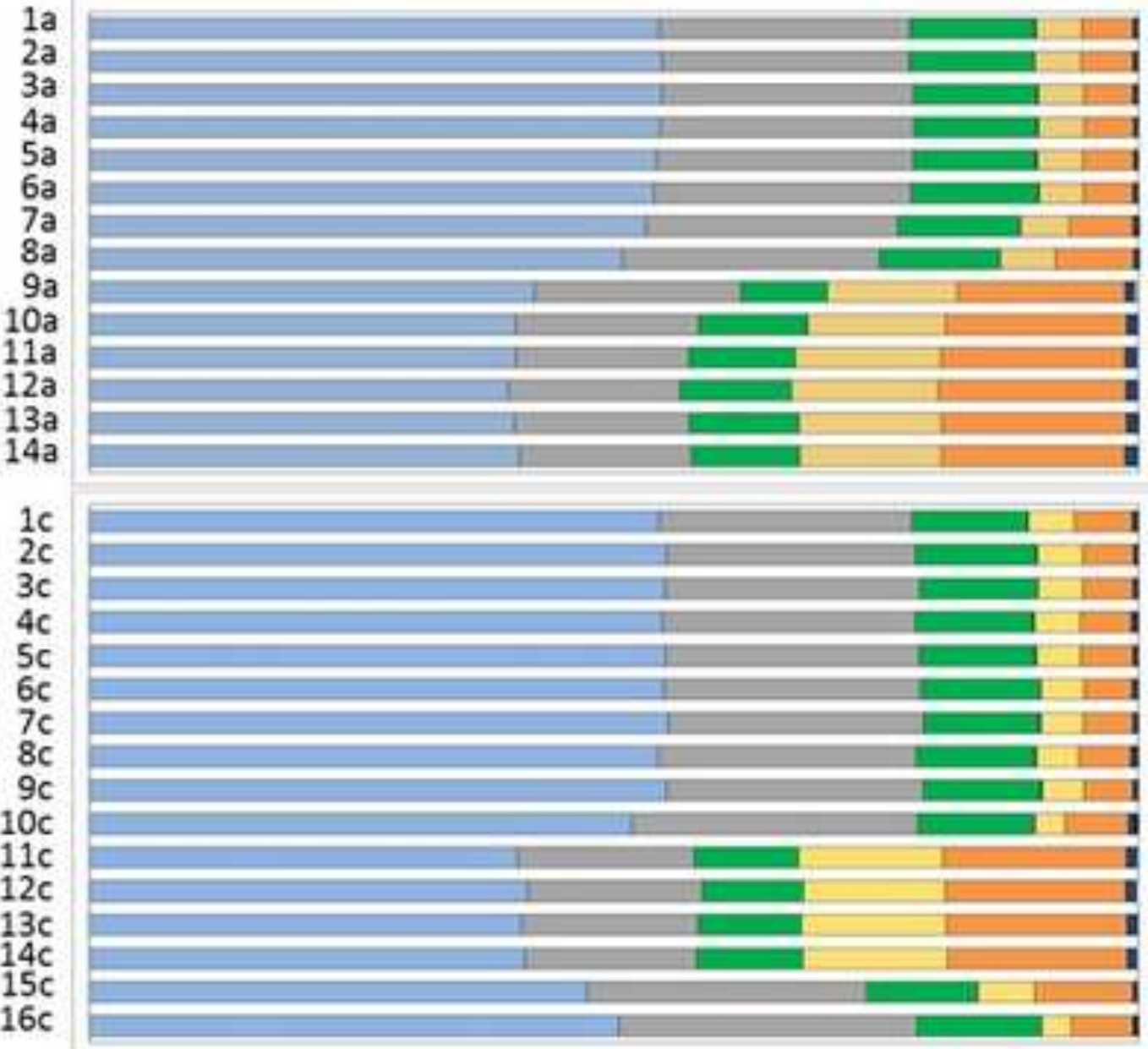




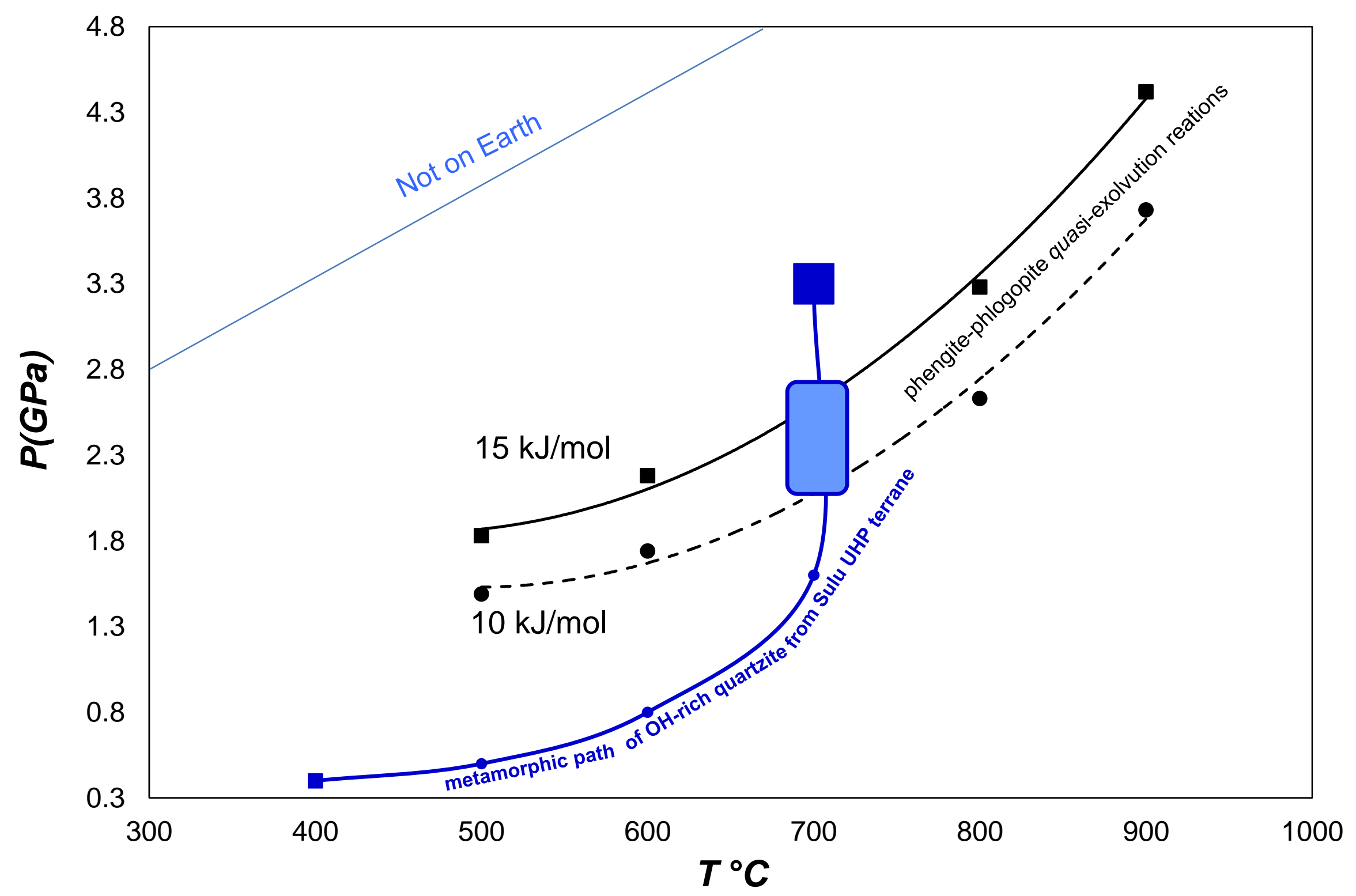


Table 1. Major element analyses (\% by weight) of Phe-3T and quasi-exsolved Phl-phases determined by EMP

\begin{tabular}{|c|c|c|c|c|c|c|}
\hline \multirow{2}{*}{$\begin{array}{l}\text { Sample } \\
\text { No. of }\end{array}$} & \multicolumn{2}{|c|}{ Phe-3T } & \multicolumn{2}{|l|}{ phl-3T } & \multicolumn{2}{|c|}{ phl-1M } \\
\hline & \multicolumn{2}{|l|}{4} & \multicolumn{2}{|l|}{5} & \multicolumn{2}{|l|}{9} \\
\hline $\begin{array}{l}\text { No. of } \\
\text { analyses }\end{array}$ & \multicolumn{2}{|l|}{24} & \multicolumn{2}{|l|}{15} & \multicolumn{2}{|l|}{9} \\
\hline $\mathrm{SiO}_{2}$ & 50.76 & $(49.00-51.69)$ & 39.35 & $(38.27-40.50)$ & 37.80 & $(37.07-38.75)$ \\
\hline $\mathrm{Al}_{2} \mathrm{O}_{3}$ & 23.44 & (21.73-25.04) & 15.00 & (14.88-15.93) & 14.87 & $(13.98-15.75)$ \\
\hline $\mathrm{K}_{2} \mathrm{O}$ & 10.83 & $(9.90-11.31)$ & 7.96 & $(7.69-8.35)$ & 8.76 & $(8.06-9.98)$ \\
\hline $\mathrm{Na}_{2} \mathrm{O}$ & 0.04 & $(0.01-0.08)$ & 0.04 & $(0.00-0.07)$ & 0.03 & $(0.00-0.08)$ \\
\hline $\mathrm{CaO}$ & 0.00 & $(0.00-0.00)$ & 0.00 & $(0.00-0.00)$ & 0.16 & $(0.10-0.24)$ \\
\hline $\mathrm{BaO}$ & 0.25 & $(0.16-0.35)$ & 0.03 & $(0.00-0.16)$ & 0.00 & $(0.00-0.00)$ \\
\hline $\mathrm{MgO}$ & 4.02 & $(3.73-4.40)$ & 13.10 & (12.70-13.36) & 12.58 & $(12.32-12.81)$ \\
\hline $\mathrm{FeO}$ & 1.92 & $(1.75-2.21)$ & 14.22 & (13.26-14.91) & 16.40 & $(16.03-16.76)$ \\
\hline $\mathrm{Fe}_{2} \mathrm{O}_{3}$ & 2.53 & $(2.30-2.94)$ & - & - & - & - \\
\hline $\mathrm{TiO}_{2}$ & 0.48 & $(0.42-0.55)$ & 1.10 & $(0.67-1.29)$ & 0.99 & $(0.90-1.04)$ \\
\hline $\mathrm{MnO}$ & 0.00 & $(0.00-0.00)$ & 0.05 & $(0.00-0.11)$ & 0.07 & $(0.00-0.13)$ \\
\hline $\mathrm{F}^{-}$ & 0.00 & $(0.00-0.00)$ & 0.92 & $(0.00-1.82)$ & 0.00 & $(0.00-0.00)$ \\
\hline $\mathrm{Cl}^{-}$ & 0.00 & $(0.00-0.00)$ & 0.02 & $(0.00-0.05)$ & 0.00 & $(0.00-0.00)$ \\
\hline Total & 94.27 & (90.40-96.78) & 92.03 & $(90.22-93.71)$ & 91.73 & $(90.73-93.29)$ \\
\hline \multicolumn{7}{|l|}{ a.p.f.u. } \\
\hline $\mathrm{Si}^{4+}$ & 3.46 & $(3.42-3.55)$ & 2.97 & $(2.96-3.17)$ & 2.88 & $(2.84-3.02)$ \\
\hline $\mathrm{Al}^{3+}$ & 1.89 & $(1.78-1.98)$ & 1.33 & $(1.31-1.48)$ & 1.33 & $(1.28-1.44)$ \\
\hline $\mathrm{K}^{+}$ & 0.94 & $(0.88-0.99)$ & 0.77 & $(0.76-0.83)$ & 0.85 & $(0.80-0.98)$ \\
\hline $\mathrm{Na}^{+}$ & 0.01 & $(0.00-0.01)$ & 0.01 & $(0.00-0.01)$ & 0.00 & $(0.00-0.01)$ \\
\hline $\mathrm{Ca}^{2+}$ & 0.00 & $(0.00-0.00)$ & 0.00 & $(0.00-0.00)$ & 0.01 & $(0.01-0.02)$ \\
\hline $\mathrm{Ba}^{2+}$ & 0.01 & $(0.00-0.01)$ & 0.00 & $(0.00-0.00)$ & 0.00 & $(0.00-0.00)$ \\
\hline $\mathrm{Mg}^{2+}$ & 0.41 & $(0.38-0.45)$ & 1.47 & $(1.43-1.59)$ & 1.43 & $(1.39-1.49)$ \\
\hline $\mathrm{Fe}^{2+}$ & 0.11 & $(0.10-0.17)$ & 0.39 & $(0.36-0.43)$ & 0.45 & $(0.42-0.48)$ \\
\hline $\mathrm{Fe}^{3+}$ & 0.13 & $(0.12-0.19)$ & 0.46 & $(0.41-0.50)$ & 0.53 & $(0.49-0.56)$ \\
\hline $\mathrm{Ti}^{4+}$ & 0.02 & $(002-0.03)$ & 0.06 & $(0.04-0.07)$ & 0.06 & $(0.05-0.06)$ \\
\hline $\mathrm{Mn}^{2+}$ & 0.00 & $(0.00-0.00)$ & 0.00 & $(0.00-0.02)$ & 0.00 & $(0.00-0.01)$ \\
\hline $\mathrm{F}^{-}$ & 0.00 & $(0.00-0.00)$ & 0.22 & $(0.00-0.47)$ & 0.00 & $(0.00-0.00)$ \\
\hline $\mathrm{Cl}^{-}$ & 0.00 & $(0.00-0.00)$ & 0.00 & $(0.00-0.01)$ & 0.00 & $(0.00-0.00)$ \\
\hline$\Sigma$ cat & 6.98 & $(6.95-7.02)$ & 7.46 & (7.40-7.99) & 7.56 & $(7.51-7.86)$ \\
\hline$\Sigma \mathrm{cat}^{\mathrm{VI}}$ & 2.02 & $(1.99-2.05)$ & 2.69 & $(2.55-2.98)$ & 2.69 & $(2.60-2.92)$ \\
\hline
\end{tabular}

The a.p.f.u. have been calculated on the basis of 22 negative charges. $\mathrm{Fe}^{2+}$ and $\mathrm{Fe}^{3+}$ are determined using Mössbauer spectroscopy results (see supplementary materials Table S2)

Maximum and minimum observed values as in brackets; the bottom lines: the sum of total cations ( $\sum$ cat $)$ and of octahedral cations $\left(\Sigma \mathrm{cat}^{\mathrm{VI}}\right)$. 
Table 2: Major element compositions (wt $\%$ ) of phases and bulk rock used in mass balance calculations.

$\begin{array}{ccccccc} & P h e-3 T & P h l-3 T & P h l-1 M & * \text { Qtz } & * \text { K-Feld } & \text { ASV } \\ \mathrm{SiO}_{2} & 54.13 & 43.35 & 41.27 & 100 & 63.78 & 76.30 \\ \mathrm{TiO}_{2} & 0.51 & 1.21 & 1.08 & & 0.00 & 0.19 \\ \mathrm{Al}_{2} \mathrm{O}_{3} & 25.00 & 16.53 & 16.24 & & 20.46 & 13.31 \\ \mathrm{FeO} & 4.48 & 15.67 & 17.91 & & 0.24 & 2.58 \\ \mathrm{MgO} & 4.29 & 14.43 & 13.74 & & 0.00 & 1.06 \\ \mathrm{CaO} & 0.00 & 0.00 & 0.17 & & 0.51 & 0.99 \\ \mathrm{Na} 2 \mathrm{O} & 0.04 & 0.04 & 0.03 & & 1.53 & 0.99 \\ \mathrm{~K}_{2} \mathrm{O} & 11.55 & 8.77 & 9.56 & & 13.47 & 4.57\end{array}$

* = quartz (Qtz) and K-feldspar (K-feld) compositions are from metamorphic veins of Sulu -UHP terrains (Wang et al., 2014; Frezzotti et al., 2007)

AVS: bulk rock averaged compositions of Sulu metamorphic veins (Wang et al., 2014; Frezzotti et al 2007) 


\section{Supplementary : S1}

Single crystal X-ray diffraction data collection and refinement conditions.

\begin{tabular}{|c|c|c|c|}
\hline & Phe-3T & $p h l-3 T$ & $p h l-1 M$ \\
\hline$a(\AA)$ & $5.2248(6)$ & $5.3166(5)$ & $5.3195(13)$ \\
\hline$b(\AA)$ & - & - & $9.2117(12)$ \\
\hline$c(\AA)$ & $29.737(5)$ & $30.21(2)$ & $10.210(3)$ \\
\hline$\beta\left(^{\circ}\right)$ & - & - & $100.04(2)$ \\
\hline$V\left(\AA^{3}\right)$ & $703.1(3)$ & $739.00(12)$ & $492.7(2)$ \\
\hline Space Group & $P 3_{1} 12$ & $P 3_{1} 12$ & $C 2 / m$ \\
\hline$Z$ & 3 & 3 & 2 \\
\hline Radiation & $\operatorname{MoK} \alpha$ & $\operatorname{MoK\alpha }$ & $\operatorname{MoK\alpha }$ \\
\hline Monochromator & graphite & graphite & graphite \\
\hline $2 \theta$-range $\left(^{\circ}\right)$ & 70.00 & 64.32 & 70.02 \\
\hline Independ. Refl. & 2088 & 1281 & 966 \\
\hline$\left|\mathrm{F}_{\mathrm{o}}\right|>4 \sigma\left(\left|\mathrm{F}_{\mathrm{o}}\right|\right)$ & 1828 & 753 & 750 \\
\hline Goodness of fit & 1.172 & 2.633 & 1.066 \\
\hline $\mathrm{R}\left[\left|\mathrm{F}_{\mathrm{o}}\right|>4 \sigma\left(\left|\mathrm{F}_{\mathrm{o}}\right|\right)\right]$ & 3.50 & 8.50 & 4.78 \\
\hline R (all data) & 4.34 & 12.00 & 8.73 \\
\hline Refined parameters & 97 & 33 & 57 \\
\hline
\end{tabular}


Table S2.

Mössbauer spectrum refinement results for the sample Phe-3T. From left to right: label of the doublet (with reference to Fig.5); chemical shift, $\delta$; quadrupole splitting, $\Delta E_{Q}$; linewidth, $\Gamma$; area proportions of each doublet; attribution to $\mathrm{Fe}^{2+}$ and $\mathrm{Fe}^{3+}$ corresponding number of atom in a formula unit; * marks the not-refined value.

$\begin{array}{llllllll}\text { Doublet } & \delta(\mathrm{mm} / \mathrm{s}) & \Delta E_{Q}(\mathrm{~mm} / \mathrm{s}) & \Gamma(\mathrm{mm} / \mathrm{s}) & A(\%) & \chi^{2} & \text { Attribution } & \text { a.p.f.u. } \\ \text { A } & 0.37 \pm 0.01 & 0.63 \pm 0.01 & 0.60 \pm 0.02 & 57 \pm 1 & 1.00 & \mathrm{Fe}(\mathrm{III}) \text { ott. } & 0.13 \\ \text { B } & 1.15 \pm 0.01 & 2.98 \pm 0.01 & 0.21 \pm 0.02 & 21 \pm 1 & & \mathrm{Fe}(\mathrm{II}) \text { ott. } & 0.05 \\ \text { C } & 1.15^{*} & 2.73 \pm 0.08 & 0.56 \pm 0.07 & 22 \pm 1 & & \mathrm{Fe}(\mathrm{II}) \text { ott. } & 0.06\end{array}$


Table S3 Refined number of electrons (e-), atom positions (xyz) and isotropic equivalent displacement factors $\left(\mathrm{U}_{\mathrm{eq}}\right)$. Phe-3T, first line; Phl-3T, second line; Phl-1M, third line; esd's values between brackets.

\begin{tabular}{|c|c|c|c|c|c|}
\hline Atom & $e^{-}$ & $x$ & $y$ & $z$ & Ueq \\
\hline \multirow[t]{3}{*}{ I } & $19.2(1)$ & $0.1278(1)$ & $0.2556(2)$ & 0.16667 & $0.0268(2)$ \\
\hline & $16.9(2)$ & $0.108(1)$ & $0.217(3)$ & 0.16667 & $0.0267(9)$ \\
\hline & $17.85(18)$ & 0.00000 & 0.50000 & 0.00000 & $0.0394(5)$ \\
\hline \multirow[t]{3}{*}{ M1 } & $0.3(1)$ & $0.11(3)$ & $0.55(1)$ & 0.00000 & - \\
\hline & - & $0.146(2)$ & $0.573(1)$ & 0.00000 & $0.0100(4)$ \\
\hline & $14.17(14)$ & 0.00000 & 0.00000 & 0.50000 & $0.0095(3)$ \\
\hline \multirow[t]{3}{*}{ M2 } & $14.3(2)$ & $0.7976(2)$ & $0.8988(1)$ & 0.00000 & $0.0099(3)$ \\
\hline & - & $0.805(2)$ & $0.9024(9)$ & 0.00000 & $0.0100(4)$ \\
\hline & $14.18(12)$ & 0.00000 & $0.3338(1)$ & 0.50000 & $0.0090(2)$ \\
\hline \multirow[t]{3}{*}{ M3 } & $14.7(2)$ & $0.4550(2)$ & $0.2275(1)$ & 0.00000 & $0.0104(3)$ \\
\hline & - & $0.473(3)$ & $0.237(1)$ & 0.00000 & $0.0100(4)$ \\
\hline & - & - & - & - & - \\
\hline \multirow[t]{3}{*}{$\mathbf{T 1}$} & - & $0.7863(1)$ & $0.5811(1)$ & $0.09034(2)$ & $0.0099(2)$ \\
\hline & & $0.789(3)$ & $0.559(3)$ & $0.0900(6)$ & $0.0053(4)$ \\
\hline & & $0.0759(2)$ & $0.16716(8)$ & $0.22616(9)$ & $0.0158(2)$ \\
\hline \multirow[t]{3}{*}{$\mathbf{T} 2$} & - & $0.4680(1)$ & $0.9215(1)$ & $0.09037(2)$ & $0.0098(2)$ \\
\hline & & $0.457(2)$ & $0.905(2)$ & $0.0924(4)$ & $0.0053(4)$ \\
\hline & & - & - & - & - \\
\hline \multirow[t]{3}{*}{01} & - & $0.6543(5)$ & $0.7773(5)$ & $0.11294(6)$ & $0.0160(3)$ \\
\hline & & $0.648(7)$ & $0.755(6)$ & $0.1103(9)$ & $0.0038(6$ \\
\hline & & $0.0158(7)$ & 0.00000 & $0.1705(4)$ & $0.0264(7)$ \\
\hline \multirow[t]{3}{*}{$\mathbf{O 2}$} & - & $0.1272(5)$ & $0.7168(5)$ & $0.10722(6)$ & $0.0172(3)$ \\
\hline & & $0.118(7)$ & $0.690(6)$ & $0.1103(9)$ & $0.0038(6)$ \\
\hline & & $0.3261(5)$ & $0.2297(3)$ & $0.1684(3)$ & $0.0254(5)$ \\
\hline \multirow[t]{3}{*}{$\mathbf{O 3}$} & - & $0.6004(5)$ & $0.2506(6)$ & $0.11251(6)$ & $0.0169(3)$ \\
\hline & & $0.571(7)$ & $0.232(8)$ & $0.109(1)$ & $0.0038(6$ \\
\hline & & $0.1314(5)$ & $0.1687(2)$ & $0.3912(3)$ & $0.0175(4)$ \\
\hline \multirow[t]{3}{*}{ O4 } & - & $0.7513(5)$ & $0.5671(5)$ & $0.03590(6)$ & $0.0138(3)$ \\
\hline & & $0.760(4)$ & $0.559(4)$ & $0.038(1)$ & $0.0038(6)$ \\
\hline & & $0.1286(7)$ & 0.50000 & $0.3989(4)$ & $0.0200(6)$ \\
\hline \multirow[t]{3}{*}{05} & - & $0.5024(5)$ & $0.9406(4)$ & $0.03603(6)$ & $0.0145(3)$ \\
\hline & & $0.521(8)$ & $0.954(9)$ & $0.035(1)$ & $0.0038(6)$ \\
\hline & & - & - & - & - \\
\hline \multirow{3}{*}{ O6 } & - & $0.1249(6)$ & $0.1908(5)$ & $0.03492(6)$ & $0.0189(5)$ \\
\hline & & $0.150(4)$ & $0.230(4)$ & $0.036(6)$ & $0.0038(6$ \\
\hline & & - & - & - & - \\
\hline H $($ Phe-3T) & - & $0.11(2)$ & $0.32(2)$ & $0.039(3)$ & $0.021(9)$ \\
\hline
\end{tabular}


Table S4. Cation-oxygen bond lengths in Phe-3T, Phl-3T and Phl-1M. Estimated standard deviations in parentheses.

\begin{tabular}{|c|c|c|c|c|}
\hline & Phe-3T & $P h l-3 T$ & & $P h l-1 M$ \\
\hline $\mathrm{T} 1-\mathrm{O} 1 \AA$ & $1.638(2)$ & $1.673(10)$ & T1-O1 & $1.6536(12)$ \\
\hline $\mathrm{T} 1-\mathrm{O} 2 \AA$ & $1.631(2)$ & $1.638(9)$ & $\mathrm{T} 1-\mathrm{O} 2 \AA$ & $1.651(2)$ \\
\hline T1-O3 A & $1.636(2)$ & $1.649(11)$ & $\mathrm{T} 1-\mathrm{O} 2 \AA$ & $1.6558(19)$ \\
\hline $\mathrm{T} 1-\mathrm{O} 4 \AA$ & $1.619(2)$ & $1.564(11)$ & T1-O3 A & $1.649(2)$ \\
\hline$\langle\mathrm{T} 1-\mathrm{O}\rangle \AA$ & $1.631(1)$ & $1.631(10)$ & $\langle\mathrm{T} 1-\mathrm{O}\rangle \AA$ & $1.652(1)$ \\
\hline $\mathrm{T} 2-\mathrm{O} 1 \AA$ & $1.616(2)$ & $1.668(10)$ & - & - \\
\hline $\mathrm{T} 2-\mathrm{O} 2 \AA$ & $1.638(2)$ & $1.669(9)$ & - & - \\
\hline T2-O3 Å & $1.631(2)$ & $1.618(4)$ & - & - \\
\hline T2-O5 Å & $1.638(2)$ & $1.760(20)$ & - & - \\
\hline$\langle\mathrm{T} 2-\mathrm{O}\rangle \AA$ & $1.631(1)$ & $1.679(10)$ & - & - \\
\hline M1-O4 A (x2) & $2.18(7)$ & $2.326(11)$ & M1-O3 Å (x2) & $2.0998(18)$ \\
\hline M1-O5 А (x2) & $2.29(7)$ & $2.273(18)$ & M1-O3 A (x2) & $2.0998(18)$ \\
\hline M1-OH Å (x2) & $2.202(3)$ & $2.136(15)$ & $\mathrm{M} 1-\mathrm{OH} \AA \quad(\mathrm{x} 2)$ & $2.064(3)$ \\
\hline$\langle\mathrm{M} 1-\mathrm{O}\rangle \AA$ & $2.22(2)$ & $2.245(10)$ & $\langle\mathrm{M} 1-\mathrm{O}\rangle \AA$ & $2.088(1)$ \\
\hline M2-O4 A (x2) & $1.943(2)$ & $2.000(13)$ & M2-O3 A (x2) & $2.075(2)$ \\
\hline M2-O5 A (x2) & $1.951(2)$ & $1.95(3)$ & M2-O3 Å (x2) & $2.078(2)$ \\
\hline $\mathrm{M} 2-\mathrm{OH} \AA \quad$ (x2) & $1.981(2)$ & $2.022(12)$ & M2-OH $\AA \quad(x 2)$ & $2.030(2)$ \\
\hline$\langle\mathrm{M} 2-\mathrm{O}\rangle \AA$ & $1.958(1)$ & $1.991(8)$ & $\langle\mathrm{M} 2-\mathrm{O}\rangle \AA$ & $2.061(1)$ \\
\hline M3-O4 A (x2) & $1.956(2)$ & $2.077(10)$ & - & - \\
\hline M3-O5 A (x2) & $1.966(2)$ & $1.98(3)$ & - & - \\
\hline $\mathrm{M} 3-\mathrm{OH} \AA \quad$ (x2) & $1.994(2)$ & $2.100(9)$ & - & - \\
\hline$\langle\mathrm{M} 3-\mathrm{O}\rangle \AA$ & $1.972(1)$ & $2.052(8)$ & - & - \\
\hline $\mathrm{I}-\mathrm{O} 1 \AA \quad(\mathrm{x} 2)$ & $2.980(2)$ & $2.987(6)$ & $\mathrm{I}-\mathrm{O} 1 \AA \quad(\mathrm{x} 2)$ & $2.982(3)$ \\
\hline $\mathrm{I}-\mathrm{O} 2 \AA \AA$ & $3.016(2)$ & $3.018(9)$ & $\mathrm{I}-\mathrm{O} 2 \AA \quad(\mathrm{A} 2)$ & $2.974(2)$ \\
\hline $\mathrm{I}-\mathrm{O} 3 \AA \quad(\mathrm{x} 2)$ & $2.981(2)$ & $2.965(14)$ & $\mathrm{I}-\mathrm{O} 2 \AA \quad(\mathrm{x} 2)$ & $2.974(2)$ \\
\hline$\langle\mathrm{I}-\mathrm{O}\rangle\rangle_{\text {in }} \AA$ & $2.992(1)$ & $2.990(4)$ & $\langle\mathrm{I}-\mathrm{O}\rangle_{\text {in }} \AA$ & $2.977(1)$ \\
\hline $\mathrm{I}-\mathrm{O} 1 \stackrel{\mathrm{A}}{\circ}(\mathrm{x} 2)$ & $3.143(2)$ & $3.332(6)$ & $\mathrm{I}-\mathrm{O} 1 \stackrel{\AA}{\AA} \quad(\mathrm{x} 2)$ & $3.351(3)$ \\
\hline $\mathrm{I}-\mathrm{O} 2 \AA \quad(\mathrm{x} 2)$ & $3.279(2)$ & $3.297(7)$ & $\mathrm{I}-\mathrm{O} 2 \AA \quad(\mathrm{x} 2)$ & $3.335(2)$ \\
\hline $\mathrm{I}-\mathrm{O} 3 \mathrm{~A} \quad(\mathrm{x} 2)$ & $3.156(2)$ & $3.366(14)$ & $\mathrm{I}-\mathrm{O} 2 \AA^{\circ} \quad(\mathrm{x} 2)$ & $3.335(2)$ \\
\hline$\langle\mathrm{I}-\mathrm{O}\rangle_{\text {out }} \AA$ & $3.193(1)$ & $3.332(4)$ & $\langle\mathrm{I}-\mathrm{O}\rangle_{\text {out }} \AA$ & $3.340(1)$ \\
\hline$\langle\mathrm{I}-\mathrm{O}\rangle_{\text {tot }} \AA$ & $3.093(1)$ & $3.161(4)$ & $\langle\mathrm{I}-\mathrm{O}\rangle_{\text {tot }} \AA$ & $3.159(1)$ \\
\hline$\Delta(\mathrm{I}-\mathrm{O})_{\text {in-out }} \AA$ & $0.200(1)$ & $0.342(1)$ & $\Delta(\mathrm{I}-\mathrm{O})_{\text {in-out }} \AA$ & $0.364(1)$ \\
\hline
\end{tabular}


Table S5. Sheet thickness and principal distortion parameters in Phe-3T, Phl$3 T$ and Phl-1M . Symbols: Thick: thickness; $\tau$ : tetrahedral elongation; $\alpha$ : ditrigonal rotation; $\Delta \mathrm{z}$ : tetrahedral tilting; $\Delta_{\mathrm{TM}}$ : misfit between $\mathrm{T}$ and $\mathrm{M}$ sheets; $\Psi$ : octahedral flattening; BLD: bond length distortion; TAV: tetrahedral angle variance; ELD: edge length distortion; J: counter rotation.

\begin{tabular}{|c|c|c|c|}
\hline & Phe-3T & phl-3T & phl-1M \\
\hline Thick $(\mathrm{T})(\AA)$ & $2.241(2)$ & $2.216(8)$ & $2.261(3)$ \\
\hline Thick (M) (̊) & $2.131(2)$ & $2.212(8)$ & $2.161(3)$ \\
\hline Thick (I) $(\AA)$ & $3.305(2)$ & $3.410(8)$ & $3.453(3)$ \\
\hline$\alpha\left(^{\circ}\right)$ & 4.48 & 7.52 & 8.00 \\
\hline$\Delta \mathrm{z} \AA$ & 0.15 & 0.01 & 0.01 \\
\hline$\Delta_{\mathrm{TM}} \AA$ & 0.75 & 0.71 & 0.45 \\
\hline$\tau(\mathrm{T} 1)\left(^{\circ}\right)$ & 112.12 & 111.38 & 110.3 \\
\hline$\tau(\mathrm{T} 2)\left(^{\circ}\right)$ & 112.16 & 109.15 & - \\
\hline BLD\% (T1) & 0.35 & 2.05 & 0.14 \\
\hline BLD\% (T2) & 0.46 & 2.42 & - \\
\hline TAV (T1) & 9.96 & 22.84 & 0.87 \\
\hline TAV (T2) & 10.16 & 37.47 & - \\
\hline ELD\% (T1) & 1.44 & 1.80 & 0.62 \\
\hline ELD\% (T2) & 1.39 & 2.93 & - \\
\hline$\Psi(\mathrm{M} 1)\left(^{\circ}\right)$ & 61.38 & 60.47 & 58.83 \\
\hline$\Psi(\mathrm{M} 2)\left(^{\circ}\right)$ & 57.04 & 56.24 & 58.38 \\
\hline$\Psi(\mathrm{M} 3)\left(^{\circ}\right)$ & 57.31 & 57.39 & - \\
\hline BLD (M1)( \%) & 1.98 & 3.22 & 0.76 \\
\hline BLD (M2) (\%) & 0.77 & 1.36 & 1.00 \\
\hline BLD (M3) (\%) & 0.76 & 2.35 & - \\
\hline BLD (I) (\%) & 3.23 & 5.41 & 2.31 \\
\hline $\mathrm{J}(\mathrm{M} 1)\left(^{\circ}\right)$ & 0.53 & 2.28 & 0.00 \\
\hline $\mathrm{J}(\mathrm{M} 2)\left(^{\circ}\right)$ & 12.19 & 11.83 & 0.88 \\
\hline $\mathrm{J}(\mathrm{M} 3)\left(^{\circ}\right)$ & 12.70 & 9.55 & - \\
\hline ELD\% (M1) & 14.79 & 6.70 & 5.31 \\
\hline ELD\% (M2) & 3.44 & 4.59 & 4.53 \\
\hline ELD\% (M3) & 6.48 & 5.77 & - \\
\hline
\end{tabular}


